\title{
The TerraSAR-X Mission and System Design
}

\author{
Rolf Werninghaus and Stefan Buckreuss
}

\begin{abstract}
This paper describes the TerraSAR-X mission concept within the context of a public-private partnership (PPP) agreement between the German Aerospace Center (DLR) and the industry. It briefly describes the PPP concept as well as the overall project organization. This paper then gives an overview of the satellite design and the corresponding ground segment, as well as the main mission parameters. After a short introduction to the scientific and commercial exploitation scheme, this paper finally focuses on the mission accomplishments achieved so far during the ongoing mission.
\end{abstract}

Index Terms - Ground segment, radar, satellite, scientific and commercial exploitation, system design, TerraSAR-X.

\section{INTRODUCTION}

O N JUNE 15, 2007, Germany's first operational radar satellite TerraSAR-X was launched into orbit. This event marked the culmination point of a long and successful synthetic aperture radar (SAR) technology development line, which has been initiated and supported by the German Aerospace Center (DLR) together with the German industry since the late 1970s.

TerraSAR-X is Germany's first national remote sensing satellite being implemented in a public-private partnership (PPP) between DLR and EADS Astrium GmbH. TerraSAR-X supplies high-quality radar data for purposes of scientific observation of the Earth for a period of at least five years. At the same time, it is designed to satisfy the steadily growing demand of the private sector for remote sensing data in the commercial market.

The TerraSAR-X mission [1] is the continuation of the scientifically and technologically successful radar missions X-SAR and the Shuttle Radar Topography Mission, which have been conducted in cooperation with the National Aeronautics and Space Administration and the Italian Space Agency (ASI) in 1994 and 2000. In parallel to these missions, the national technology developments DESA (X-band SAR antenna demonstrator) and TOPAS (technology development for onboard SAR processing and storage demonstrator) have been brought forward, which have prepared the floor for the national implementation of a complex SAR mission like TerraSAR-X.

Today, remote sensing data and the derived information products about the Earth are needed not only for scientific purposes but also for a variety of private business applications. Therefore, TerraSAR-X aims to hand over the acquisition of

Manuscript received February 27, 2009; revised June 18, 2009.

R. Werninghaus is with the Earth Observation Department, German Space Agency, German Aerospace Center (DLR), 53227 Bonn, Germany (e-mail: rolf.werninghaus@dlr.de).

S. Buckreuss is with the Microwaves and Radar Institute, German Aerospace Center (DLR), 82234 Wessling, Germany (e-mail: stefan.buckreuss@dlr.de).

Color versions of one or more of the figures in this paper are available online at http://ieeexplore.ieee.org.

Digital Object Identifier 10.1109/TGRS.2009.2031062 such data to the private sector in the long run, turning it into a self-supporting sustainable business.

In this context, TerraSAR-X serves two main goals: The first goal is to provide the scientific community with multimode X-band SAR data. The broad spectrum of scientific application areas includes hydrology, geology, climatology, oceanography, environmental monitoring, and disaster monitoring, as well as cartography (digital elevation model (DEM) generation) and interferometry [2]. Representing the federal government, DLR will be the sole owner of the TerraSAR-X data and coordinates their scientific utilization.

The second goal is the establishment of a commercial Earth observation (EO) market in Europe, i.e., the development of a sustainable EO business so that follow-on systems can completely be financed by the industry from the profit. Taking into account the expected business development, the PPP agreement is aiming at the following:

1) the self-sustainability of the business;

2) the implementation and operation of a follow-on system TerraSAR-X2 by the industry;

3) the scientific exploitation rights for DLR for TerraSAR-X2.

If the business develops as foreseen today, EADS Astrium $\mathrm{GmbH}$ will finance a follow-on system after the satellite's service life has ended, thus securing the continuity of the business.

\section{PRoJECT ORGANIZATION}

\section{A. Public-Private Partnership}

TerraSAR-X is the first space project in Germany that has been realized in a PPP, with considerable financial contribution by the industry [3]. The partnership model is based on a cooperation agreement that was signed by DLR and EADS Astrium $\mathrm{GmbH}$ on March 25, 2002. The objective is for equal partners to cooperate, with each making an equitable contribution toward a joint project in order to meet their own needs. Going beyond the traditional process of awarding government-funded contracts, this approach is based on a cooperative project management. Having different objectives, both sides contribute their resources, jointly implementing the project and utilizing its results afterward. The advantage of this approach is that it permits meeting scientific goals while supporting industrial marketing needs at the same time. In this way, investments are secured which a single partner would be unable to provide on its own.

Under the partnership agreement, EADS Astrium GmbH has been awarded a contract by DLR to develop, build, and launch the satellite. For its part, DLR developed the corresponding ground segment as described in Section III-C. DLR has also set up the science service segment and took over the responsibility 


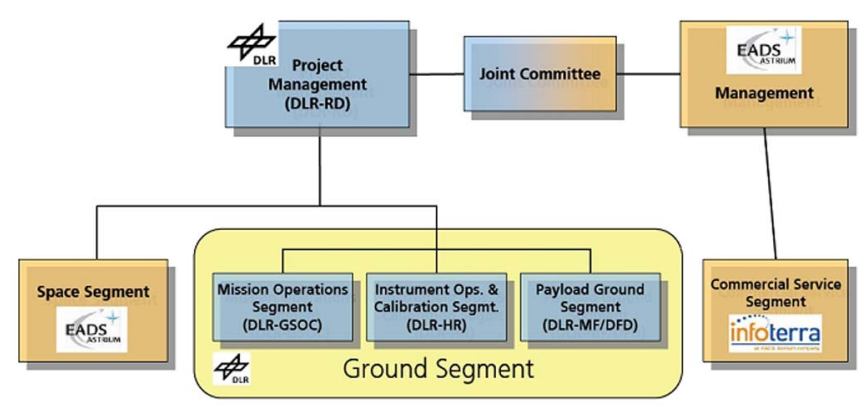

Fig. 1. Block diagram of the TerraSAR-X project structure with its governing body of the Joint Committee, as well as the three main elements space, ground, and service segment.

to provide data to the science community as explained in Section IV. In addition, DLR is responsible for the operation of the satellite over a period of five years.

EADS Astrium undertook to set up a distribution system and commercialize the TerraSAR-X data and products through its fully owned subsidiary Infoterra $\mathrm{GmbH}$. In return for the exclusive right to commercialize the TerraSAR-X data, EADS Astrium $\mathrm{GmbH}$ agreed to contribute to the development cost of the satellite. In addition, EADS Astrium contributed with a sales-dependent share of the operating cost for the satellite during its operational phase and invested considerable sums in marketing the satellite's data and products.

\section{B. Project Structure}

The overall project management for the TerraSAR-X project is located in the directorate for space projects (DLR-RD) in Bonn, as shown in Fig. 1. Under contract to DLR, EADS Astrium $\mathrm{GmbH}$ in Friedrichshafen, Germany, has developed the TerraSAR-X satellite, whereas the DLR institutes in Oberpfaffenhofen provided the related ground segment.

Within this context, DLR has the following responsibilities:

1) overall project management;

2) management of the TerraSAR-X contract with Astrium;

3) mission management;

4) science coordination;

5) development of the ground segment;

6) system engineering, calibration/verification;

7) satellite and instrument operations (German Space Operation Center (GSOC): Weilheim station);

8) data reception (Neustrelitz), processing, archiving, and distribution.

EADS Astrium/Infoterra, on the other hand, was in charge of the development, assembly, and launch of the TerraSAR-X satellite (as contractor to DLR), as well as of the businessrelated activities like the following:

1) X-band-based product research and development;

2) X-band-based market development;

3) development of a commercial service segment;

4) commercial exploitation of the TerraSAR- $X$ data;

5) implementation and operation of a follow-on system TerraSAR-X2.

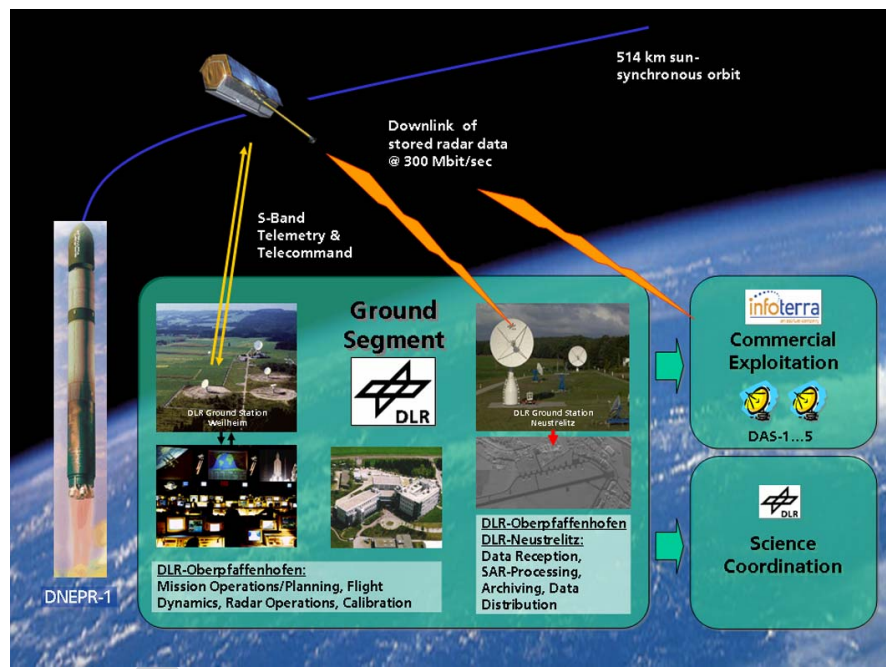

Fig. 2. General TerraSAR-X mission concept showing the command and data streams from/to the Mission Control Center in Oberpfaffenhofen and the DLR ground stations in Weilheim and Neustrelitz, as well as the Infoterra DAS of commercial customers and the science user community represented by the science coordinator.

\section{Mission AND System Design}

\section{A. Mission Design}

The TerraSAR-X satellite [4] was launched from Baikonur on a Russian/Ukrainian Dnepr-1 launch vehicle with a $1.5-\mathrm{m}-$ long fairing extension. A sun-synchronous dawn-dusk orbit with an 11-day repeat period was selected as a good compromise between radar performance, order to-acquisition time, and revisit time. Once in the orbit, the satellite has been taken over by the Mission Control Center in Oberpfaffenhofen. The system baseline includes two ground stations in Germany. Weilheim is used as the satellite control station, and Neustrelitz serves as the central receiving station for the $300-\mathrm{Mb} / \mathrm{s} \mathrm{X}$-band downlink (Fig. 2). Beyond that up to now, five additional direct access stations (DAS) - receiving stations of commercial partners of Infoterra $\mathrm{GmbH}$ - have been set up to extend the baseline receiving station concept [1]. More DAS may be added in the future.

\section{B. TerraSAR-X Satellite}

The TerraSAR-X satellite bus (see also the related TGRS article [5] in this Special Issue) is a heritage from the successful CHAMP and GRACE missions [6]. The satellite configuration of TerraSAR-X is shown in Fig. 3. TerraSAR-X features an advanced high-resolution X-band SAR based on the active phased array technology [7], [8] which allows the operation in spotlight, stripmap, and ScanSAR mode with two polarizations in various combinations (see Table I). It combines the ability to acquire high-resolution images for detailed analysis, as well as wide-swath images for overview applications [9]. The experimental dual-receive antenna (DRA) mode [10] allows receiving independently the echoes from the two azimuth antenna halves. This new experimental mode enables the use of interesting new features like along-track interferometry, full-polarimetric data acquisition, and the enhancement of stripmap azimuth resolution [11]. 


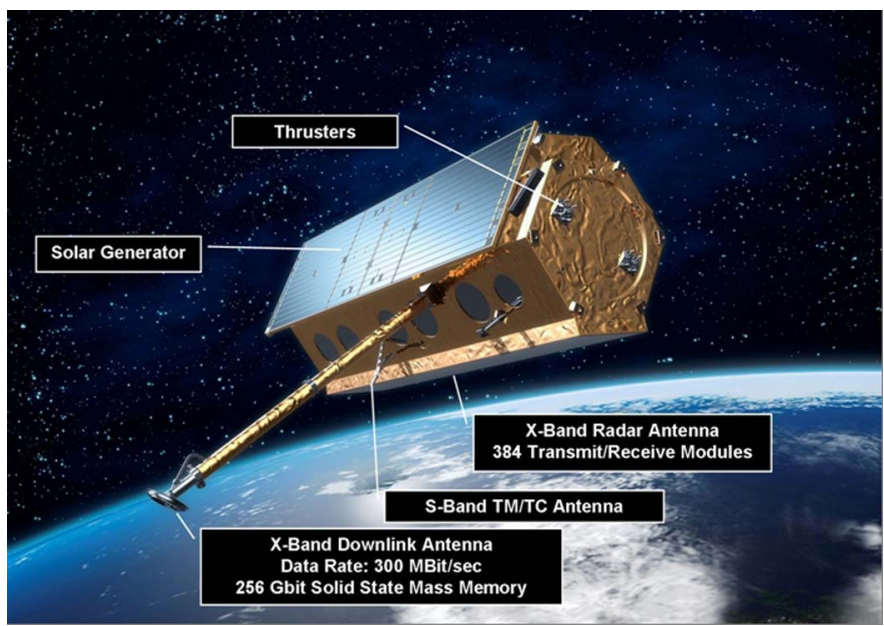

Fig. 3. Artist view of the TerraSAR-X satellite. Note the (upper left) solar generator, the (lower left) boom with the X-band downlink antenna, and the (lower right) $\mathrm{X}$-band radar antenna.

TABLE I

Main TERraSAR-X System Parameters

\begin{tabular}{|c|c|}
\hline Height: & $4.88 \mathrm{~m}$ \\
\hline Width: & $2.4 \mathrm{~m}$ \\
\hline Launch Mass: & $\begin{array}{l}1.230 \mathrm{~kg} \\
\text { (including payload mass } 400 \mathrm{~kg} \text { ) }\end{array}$ \\
\hline Orbit height: & $514 \mathrm{~km}$ \\
\hline Inclination: & $97.4^{\circ}$, sun-synchronous \\
\hline Orbit tube: & $250 \mathrm{~m}$ radius \\
\hline $\begin{array}{l}\text { Orbit maintenance } \\
\text { frequency: }\end{array}$ & $\begin{array}{l}\text { between } 1 / \text { week and } 1 / \text { day } \\
\text { (depending on solar activity) }\end{array}$ \\
\hline $\begin{array}{l}\text { Orbit determination } \\
\text { accuracy: }\end{array}$ & $\begin{array}{l}\text { better than } 20 \mathrm{~cm} \\
\text { (with 2-frequency GPS) }\end{array}$ \\
\hline Imaging capability: & up to $300 \mathrm{sec} /$ orbit \\
\hline Launcher: & Dnepr-1 (former SS-18) \\
\hline Launch: & $\begin{array}{l}15 \text { June } 2007,4: 14 \text { h (CEST) } \\
\text { From Baikonur, Kazakhstan }\end{array}$ \\
\hline Life time: & $\begin{array}{l}5 \text { years } \\
\text { (consumables up to } 7 \text { years) }\end{array}$ \\
\hline Radar frequency: & $9.65 \mathrm{GHz}$ \\
\hline Transmit bandwidth: & $\begin{array}{l}5 \ldots . .150 \mathrm{MHz} \text { nominal } \\
300 \mathrm{MHz} \text { experimental }\end{array}$ \\
\hline Polarization: & $\mathrm{HH} / \mathrm{VV} / \mathrm{HV} / \mathrm{VH}$ \\
\hline $\begin{array}{l}\text { Stripmap Mode: } \\
\text { [Range x Azimuth] }\end{array}$ & $\begin{array}{l}\text { Resolution: } 3 \mathrm{~m} \text { x } 3 \mathrm{~m} \\
\text { Scene Size: } 30 \mathrm{~km} \text { x } 50 \mathrm{~km}\end{array}$ \\
\hline $\begin{array}{l}\text { Spotlight Mode: } \\
\text { [Range x Azimuth] }\end{array}$ & $\begin{array}{l}\text { Resolution: } 1 \mathrm{~m} \times 1.5 \mathrm{~m} \ldots 3.5 \mathrm{~m} \\
\text { Scene Size: } 10 \mathrm{~km} \times 5 \mathrm{~km} \ldots 10 \mathrm{~km}\end{array}$ \\
\hline $\begin{array}{l}\text { ScanSAR Mode: } \\
\text { [Range } x \text { Azimuth] }\end{array}$ & $\begin{array}{l}\text { Resolution: } 16 \mathrm{~m} \text { x } 16 \mathrm{~m} \\
\text { Scene Size: } 100 \mathrm{~km} \text { x } 150 \mathrm{~km}\end{array}$ \\
\hline
\end{tabular}

In addition to the SAR instrument, two secondary payloads fly on the TerraSAR-X spacecraft:

1) the laser communication terminal (LCT), a technology demonstrator for an intersatellite communication link developed by TESAT, Backnang, in contract to DLR, allowing for a $5.6-\mathrm{Gb} / \mathrm{s}$ satellite-to-satellite or satelliteto-ground communication link [12];

2) the tracking, occultation, and ranging (TOR) instrument package, a dual-frequency GPS tracking receiver and a laser reflector set for high-precision orbit determination and occultation measurements provided by the GeoForschungsZentrum Potsdam and the University of Texas Center for Space Research [13]. As shown in
Table I, TOR allows for a high-precision orbit determination accuracy of better than $20 \mathrm{~cm}$ [14].

\section{TerraSAR-X Ground Segment}

The TerraSAR-X ground segment (see also the related TGRS articles [15] and [16] in this Special Issue) is the central element for controlling and operating the TerraSAR-X satellite, for calibrating its SAR instrument, and for archiving the SAR data, as well as generating and distributing the basic data products. The overall TerraSAR-X ground infrastructure consists of two major parts:

1) the DLR-provided ground segment;

2) the commercial exploitation and service segment (TSXX) developed by Infoterra.

The DLR ground segment is based on an existing national infrastructure as much as possible and was optimized for flexible response to (scientific and commercial) user requests and fast image product turnaround times. It is composed of three major elements [17]:

1) the mission operations segment provided by GSOC for control of the satellite;

2) the instrument operation and calibration segment (see also the related TGRS articles [18] and [19] in this Special Issue) provided by the Microwaves and Radar Institute (IHR);

3) the payload ground segment for receiving, processing, archiving, calibrating, and distributing the radar data provided by the German Remote Sensing Data Center (DFD) and the DLR Remote Sensing Technology Institute (IMF).

\section{SCIENTIFIC COORDINATION AND COMMERCIAL EXPLOITATION}

TerraSAR-X is an operational SAR system for scientific and commercial applications. The commercial exploitation is exclusively granted to Astrium/Infoterra $\mathrm{GmbH}$.

DLR is responsible for the scientific utilization of the TerraSAR-X products. The status "scientific use" needs to be gained via a selection process. The Science Service System (http://sss.terrasar-x.dlr.de/) was developed for this purpose. Already prior to the launch of the TerraSAR-X satellite, a prelaunch announcement of opportunity (AO) was issued by DLR. Since the end of October 2007, new proposals can be submitted under a general $\mathrm{AO}$ at any time. Under these AOs, more than 300 scientific proposals have been accepted until mid-2009, resulting in several thousands of data acquisition requests. The corresponding TerraSAR-X data are provided to the costs of fulfilling the user request. Additional AOs are planned, where special conditions might be applied with respect to the data provision.

The relative number of proposals from the AOs in different application fields is shown in Fig. 4. As expected, the "land cover and vegetation" area is the most significant application field, as the TerraSAR-X mission has been particularly designed for land applications. Within this subgroup, there is a relatively equal distribution between urban, forest, agriculture, 


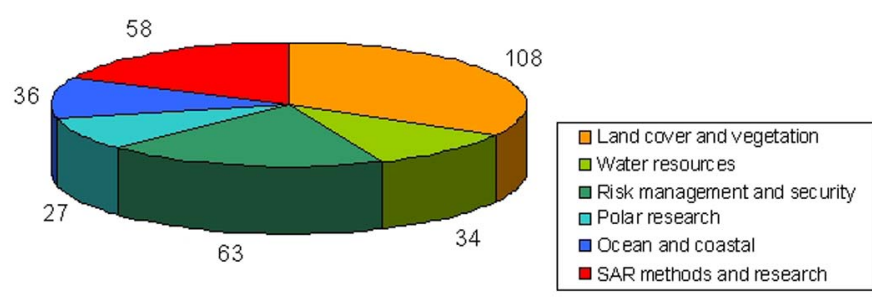

Fig. 4. Under the TerraSAR-X AOs, more than 300 scientific proposals have been accepted until mid-2009. The figure shows the relative distribution of these proposals in the different application areas.

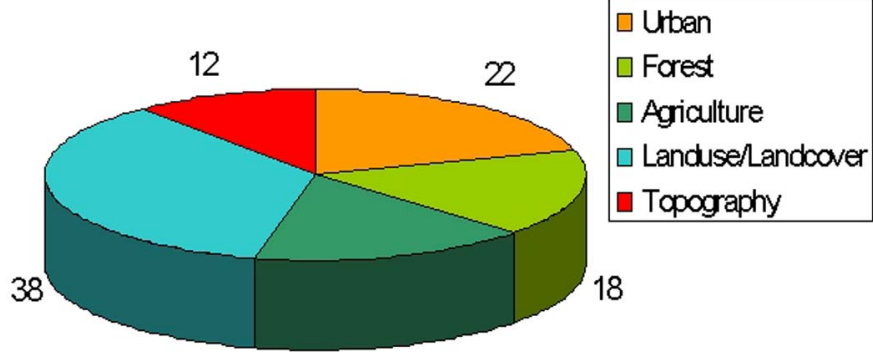

18

Fig. 5. Relative distribution of the 108 proposals in the land cover and vegetation application area in Fig. 4. Among these, the land use/land cover is the most significant field of use.

topography, and land use/land cover application areas, with the latter being the most significant field of use, as can be seen in Fig. 5.

Commercial customers, on the other hand, will have to contact Infoterra (http://www.terrasar.com/) for access to the TerraSAR-X data via the commercial TerraSAR-X exploitation and service infrastructure (TSXX) developed by Infoterra. In addition to the baseline station in Neustrelitz, Infoterra sets up additional receiving stations for dedicated commercial customers, which require fast and direct access to the TerraSAR-X data. These so-called DAS are implemented to extend the baseline receiving station concept.

\section{Mission ACCOMPLishments}

TerraSAR-X was successfully launched on June 15, 2007, 2:14 UTC, on Dnepr-1 in Baikonur, Kasachstan. During the following launch and early orbit phase (LEOP), the basic functionalities of the bus and the prime and secondary payload were checked out.

The first acquisition of the satellite telemetry occurred 15 min after launch over the European Space Agency ground station in Malindi, Kenya. Throughout the following days, the satellite systems and radar instrument were switched on and are working well since then. The $\mathrm{X}$-band data reception was switched on at LEOP day 4. The radar performance is excellent; the first image was processed already at LEOP day 5 on June 19, 2007. In the following days, all standard imaging modes (stripmap, spotlight, and ScanSAR) have been exercised successfully.

The checking out of the dual-frequency GPS receiver IGOR (secondary payload) and the LCT (secondary payload) was

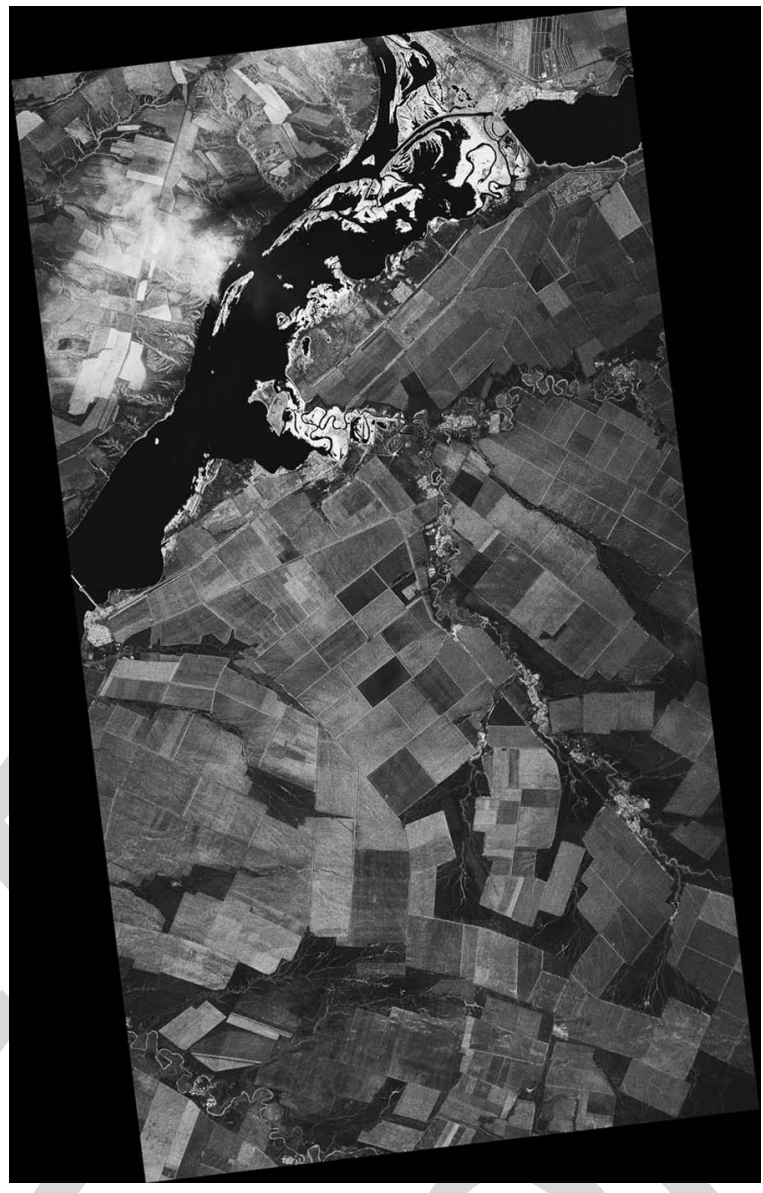

Fig. 6. First TerraSAR-X image, showing a $30 \mathrm{~km} \times 60 \mathrm{~km}$ area in Russia, western to Wolgograd. The scene has been imaged in the stripmap mode, $\mathrm{HH}$ polarization, on June 19, 2007. The resolution is approximately $15 \mathrm{~m}$.

completed as planned. The first satellite-to-satellite communication links between the TerraSAR-X LCT and the U.S. NFIRE satellite were executed successfully in the following months.

Fig. 6 shows the first image acquired by TerraSAR-X. The image shows a $30 \mathrm{~km} \times 60 \mathrm{~km}$ area in Russia, western to Wolgograd, which has been imaged in the stripmap mode with $\mathrm{HH}$ polarization. The resolution is approximately $15 \mathrm{~m}$.

In the upper half of the image, the Tsimlyanskoye reservoir can be seen. Here, the River Don is dammed with the water being used for power generation. In the immediate neighborhood, the meandering oxbow river bends can be seen as dark surfaces. Calm water surfaces are typically very dark in radar photographs since the radar radiation hitting them is reflected away. In the center left of the image, a railway bridge crosses the River Don with the railway line disappearing toward the northeast. In the lower half, large agricultural areas dominate. The different brightness of the fields results from the differing vegetation and the particular stages of their annual growth cycles.

During this survey, a thick cloud cover prevailed. Nevertheless, radar satellites such as TerraSAR-X offer imaging capability even in the case of cloudy skies and at night. However, exceptional strong precipitation events like heavy thunderstorms may influence even radar imaging. Such an event can be seen at the upper left part of the radar image as a bright "veil." 
The successful processing of this first image demonstrated the functional capability of the satellite on the one hand and the operability of the ground segment on the other hand. The entire processing chain, including order input, scheduling, commanding, data acquisition, on-ground data reception, SAR processing, and archiving of the images, has been verified. This result was also the consequence of a comprehensive prelaunch testing program, including numerous space-to-ground-segment tests.

After the successful completion of the LEOP, the commissioning phase (see also the related TGRS article [20] in this Special Issue) was started on June 22, 2007, encompassing an ambitious program with respect to the following goals [21]:

1) orbit and attitude verification [22];

2) instrument characterization/verification [23], [24];

3) overall SAR system performance characterization [21], [25] (see also the related TGRS article [26] in this Special Issue);

4) calibration of the radar data [27], [28];

a) geometric calibration;

b) antenna pointing calibration;

c) antenna model verification (see also the related TGRS article [29] in this Special Issue);

d) relative radiometric calibration;

e) absolute radiometric calibration;

f) internal instrument calibration.

5) checking out of the receiving station and processing system;

6) SAR product verification [30];

7) checking out of the DAS operated by Infoterra $\mathrm{GmbH}$;

8) load tests including the commercial service segment [31], [32];

9) interferometric processing [33], [34].

The commissioning phase was finished right on schedule after 5.5 months, and the goal was attained to ensure optimum SAR product quality and to accomplish the full operational readiness of the space and ground segment in December 2007. The TerraSAR-X team executed a very comprehensive calibration and verification program. During the commissioning phase, 12000 data takes were executed, and all imaging modes were tested and verified. In several cases, the obtained results even exceeded the initial specifications. Consequently, TerraSAR-X turned out to be a very stable precision instrument for radar imaging.

Furthermore, the potential of TerraSAR-X for repeat pass [35], as well as along-track interferometry [36] and TOPSAR [37]-[39], was shown (see also the related articles [40] and [41] in this TGRS Special Issue). Novel techniques such as the total zero Doppler steering proved their effectivity [42]. The benefit from the high resolution provided by TerraSAR-X was demonstrated for geoscientific applications, oceanography [43], and disaster monitoring [44].

Consequently, the operational phase could be kicked off on January 7, 2008, and the image production for scientific and commercial users is running extremely satisfactory since then. In the first two years of the mission, approximately 35000 data takes have been acquired by the satellite, relating to approximately 50000 data products, with a still growing trend.

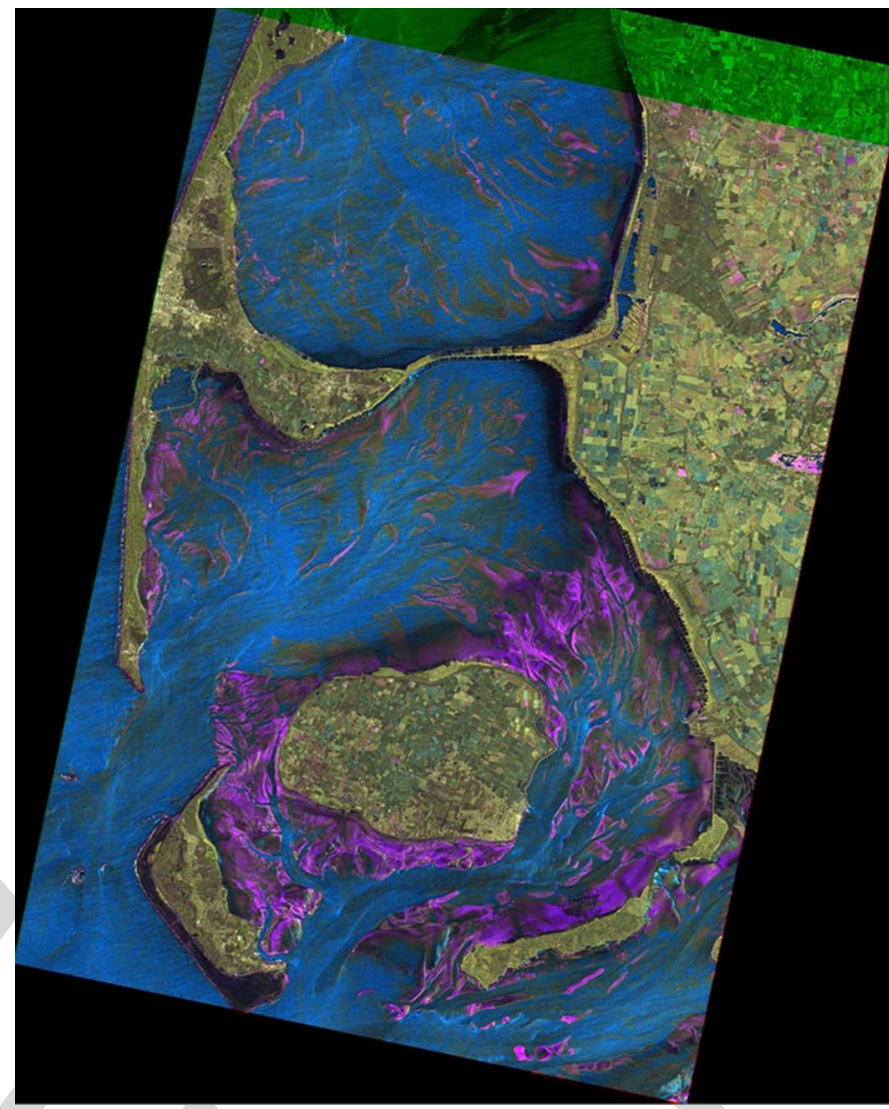

Fig. 7. Multitemporal TerraSAR-X image of mudflats near the island of Sylt, Germany. The image is a combination of two acquisitions that were taken by TerraSAR-X in April and May 2008 in stripmap mode. The individual pictures are colored red and green, respectively.

\section{EXAMPLE IMAGERY}

In the following, a few examples of TerraSAR-X imagery shall demonstrate the high quality of the data products (see also the related TGRS article [45] in this Special Issue).

The first example (Fig. 7) shows the mudflats near the island of Sylt, Germany. It was compiled from two images that were taken by TerraSAR-X in April and May 2008 in stripmap mode. The individual pictures are colored red and green, respectively. The difference in the reflected radar signals (in blue) is particularly large over the areas of water, where the most changes occurred in between the two data takes. The resulting image can be used to extensively study the morphology, sediments, and habitats in the Wadden Sea. Structures such as tidal creek courses (recognizable in the blue area) and mussel beds (light areas near the coast) are clearly shown.

The high-resolution capability of advanced radar sensors like TerraSAR-X opens up new observation opportunities particularly in urban areas. The following example (Fig. 8) shows an image of the Tokyo river island taken on March 7, 2008, in high-resolution spotlight mode with HH polarization. Due to the high resolution of the TerraSAR-X image, the details of the urban scenery, including the skyscrapers at the river shoreline, can clearly be distinguished. The small inlay in the image shows the appearance of the same scene in a Google Earth image for comparison. Note that the 3-D appearance of the towers in the 


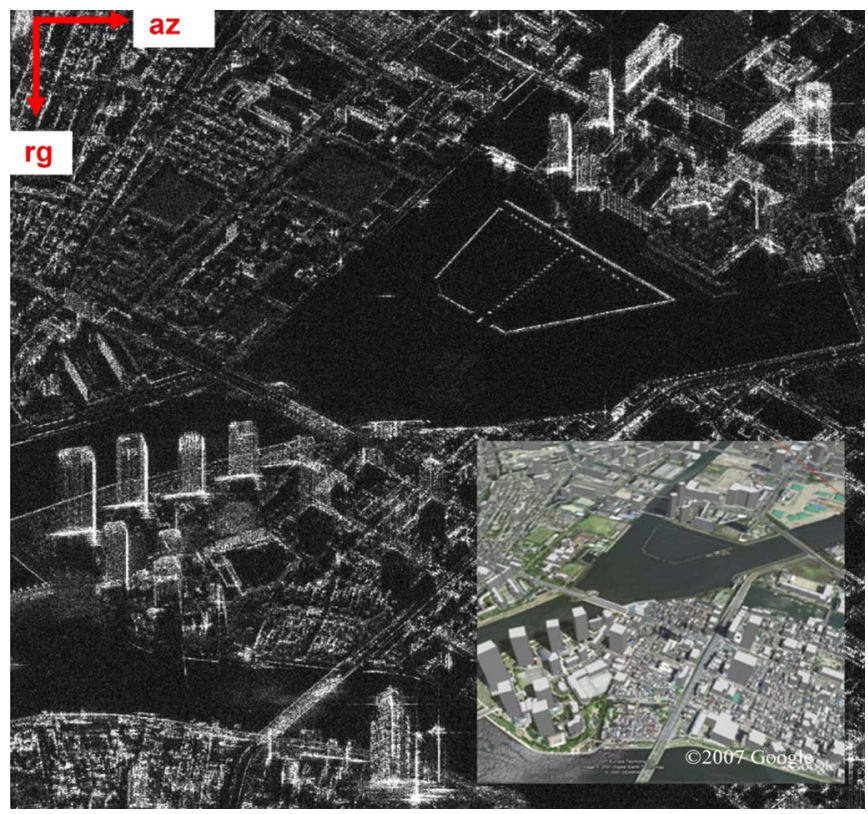

Fig. 8. High-resolution spotlight image of the Tokyo river island taken on March 7, 2008, in HH polarization with a small Google Earth image inlay for comparison.

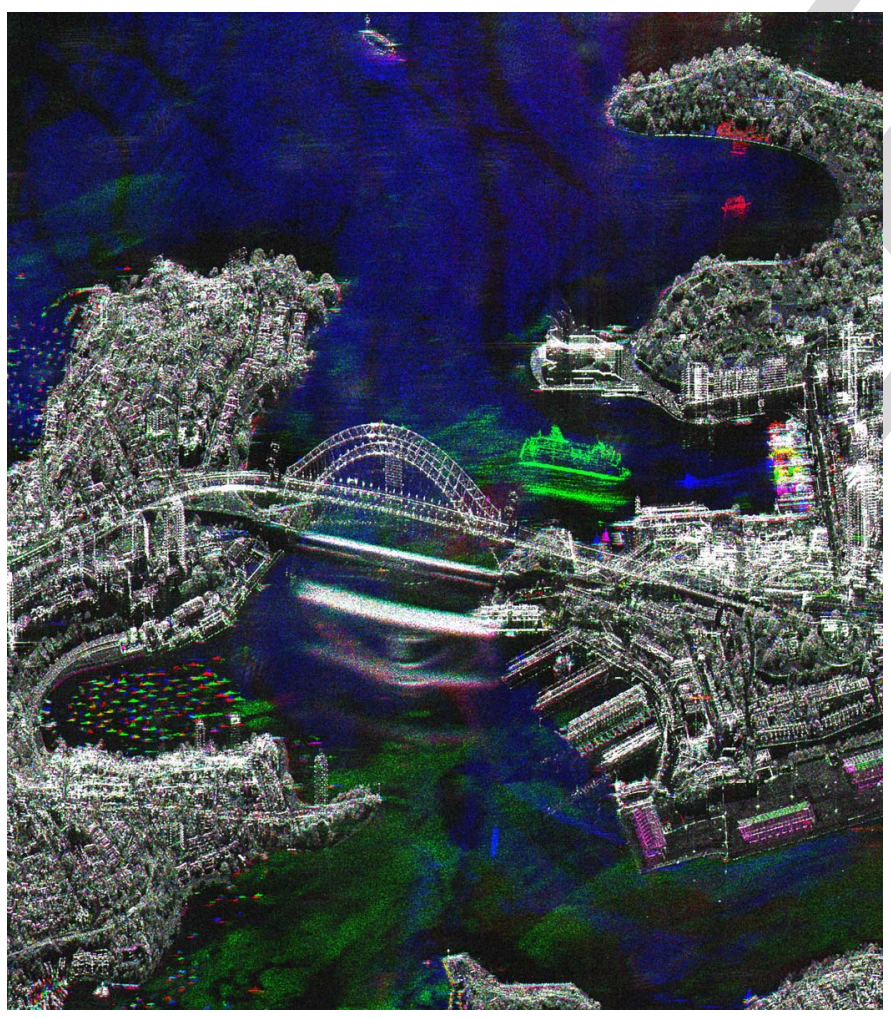

Fig. 9. Multitemporal high-resolution spotlight image of the Sydney harbor area. The three images were taken on (green) December 21, 2007, (blue) January 1, 2008, and (red) January 12, 2008. Objects, which have not changed in between the acquisitions, appear white.

radar image is due to the well-known foreshortening effect of side-looking imaging radars.

Fig. 9 also shows a high-resolution spotlight image but, this time, a multitemporal repeat-pass acquisition of the Sydney harbor area. Three color-coded images taken on December 21,

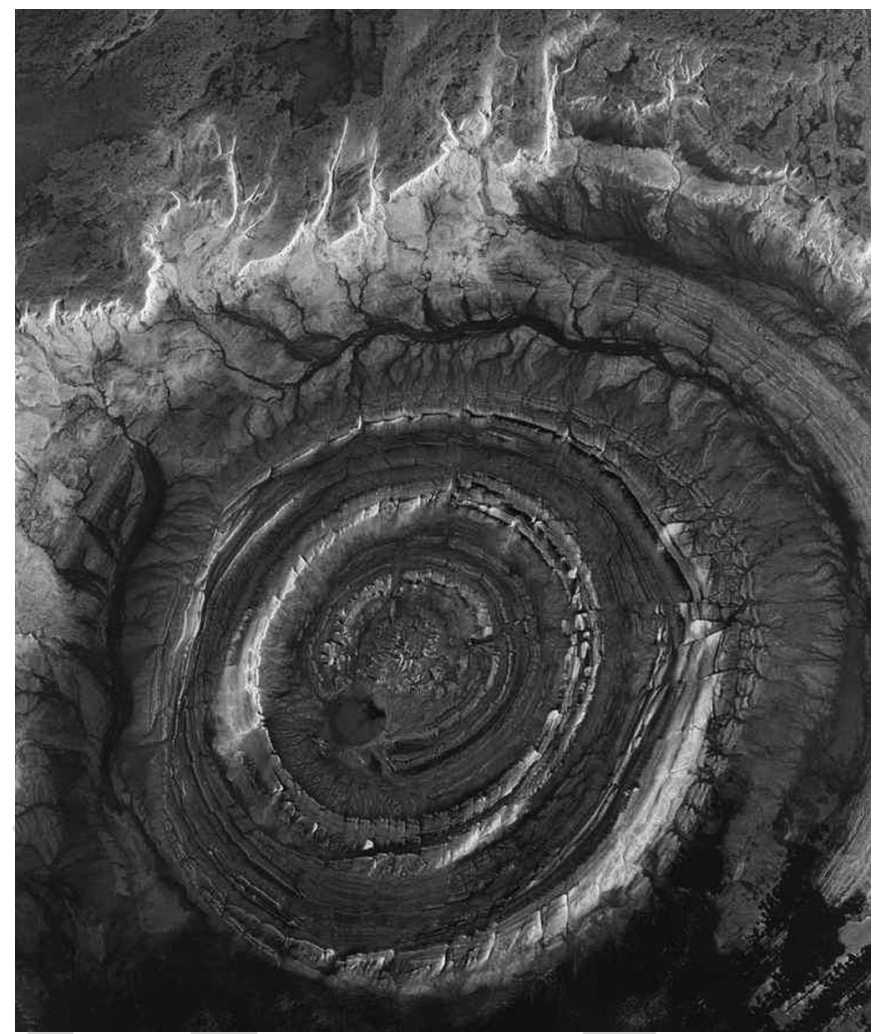

Fig. 10. TerraSAR-X image of the Guelb er Richat ring structure in Mauritania. The image was taken on July 8, 2007; original resolution: 16 m; mode: ScanSAR mode; polarization: VV.

2007 (green), January 1, 2008 (blue), and January 12, 2008 (red), have been overlayed. Objects, which have not changed in between the acquisitions, appear white. Objects, which have been present only at the time of one of the acquisitions-like the ship (green) close to the bridge-appear in the corresponding color. The radar reflection of the water surface is different in each of the images, giving the water body its special appearance. The center of the image is dominated by the impressive Sydney Harbour Bridge.

Aside from the stripmap and spotlight mode, ScanSAR is the third standard imaging mode of TerraSAR-X. It allows wide area coverage in up to $100-\mathrm{km}$-wide swathes with reduced resolution. Fig. 10 shows an image example of the Guelb er Richat in Mauritania. The ring structure shown in this image has a diameter of about $45 \mathrm{~km}$ and is located in Ouadane. The ring consists of limestones, dolomites, and breccias from the late Proterozoic to Ordovician eras (aged about 0.6 to 0.5 billion years) that were centrally uplifted and subsequently eroded. The question as to the structure's origin, which is widely thought to have been originally a meteorite crater, has not been finally answered. Although the exposed layers have formed a shallow ridge which, in many parts, is no more than a few meters high, the structure can excellently be identified and mapped in a radar image due to its surface properties.

In addition to the standard imaging modes, TerraSAR-X features the experimental DRA mode, which allows for along-track interferometry measurements (see also the related TGRS article [46] in this Special Issue), as well as fullpolarimetric data acquisitions. Fig. 11 shows an example of a 


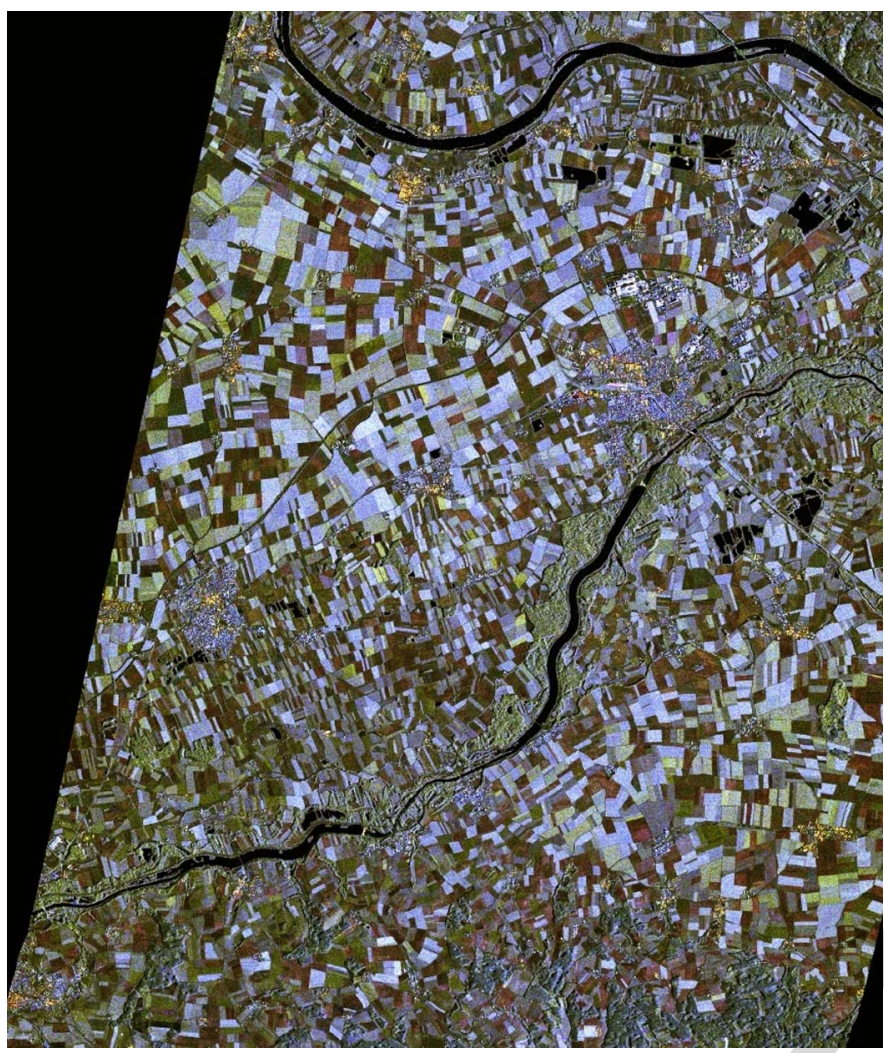

Fig. 11. One of the first images acquired in the fully polarimetric experimental mode of TerraSAR-X. The different information layers correspond to different colors. (Red) HH channel. (Green) VV channel. (Blue) (HV + VH)/2 channel.

full-polarimetric image taken in the DRA mode. The scene is located approximately $130 \mathrm{~km}$ north of Munich in the region of Deggendorf, Germany. It represents a typical agricultural cultivated area with some small forest parts and smaller urbanized areas. The use of SAR polarimetry enhances the information content because it allows separating different scattering mechanisms occurring within one resolution cell and is sensitive to the geometry and the material properties of the illuminated object. This can perfectly be illustrated by the colored image, where the different information layers correspond to different colors. The agricultural areas are represented by a variety of different colors representing the agricultural crop growth status: green fields representing nonvegetated fields, red one representing the sensitivity to the interaction between the surface and the plant stalks, and blue fields indicating dense vegetated areas. In the case that all scattering information occurs within one resolution cell, then the color combination is white.

Another outstanding feature of TerraSAR-X is its excellent interferometric performance. In combination with the high geometric resolution of the radar sensor, interesting new results can be obtained particularly in urban areas by generating high-resolution interferograms. Fig. 12 shows a zoom into a $300-\mathrm{MHz}$ high-resolution spotlight interferogram of Paris, France, at the location of the Eiffel Tower [47]. The orientation of the images generates a pseudoperspective view of the tower and larger buildings which are laid over other areas. The images were taken on January 16 and 27, 2008, with a 300-MHz range bandwidth at an incidence angle of $34.7^{\circ}$ and a baseline of $49 \mathrm{~m}$. One fringe corresponds to a 321-m height difference which is, by chance, exactly the height of the tower. The orig-

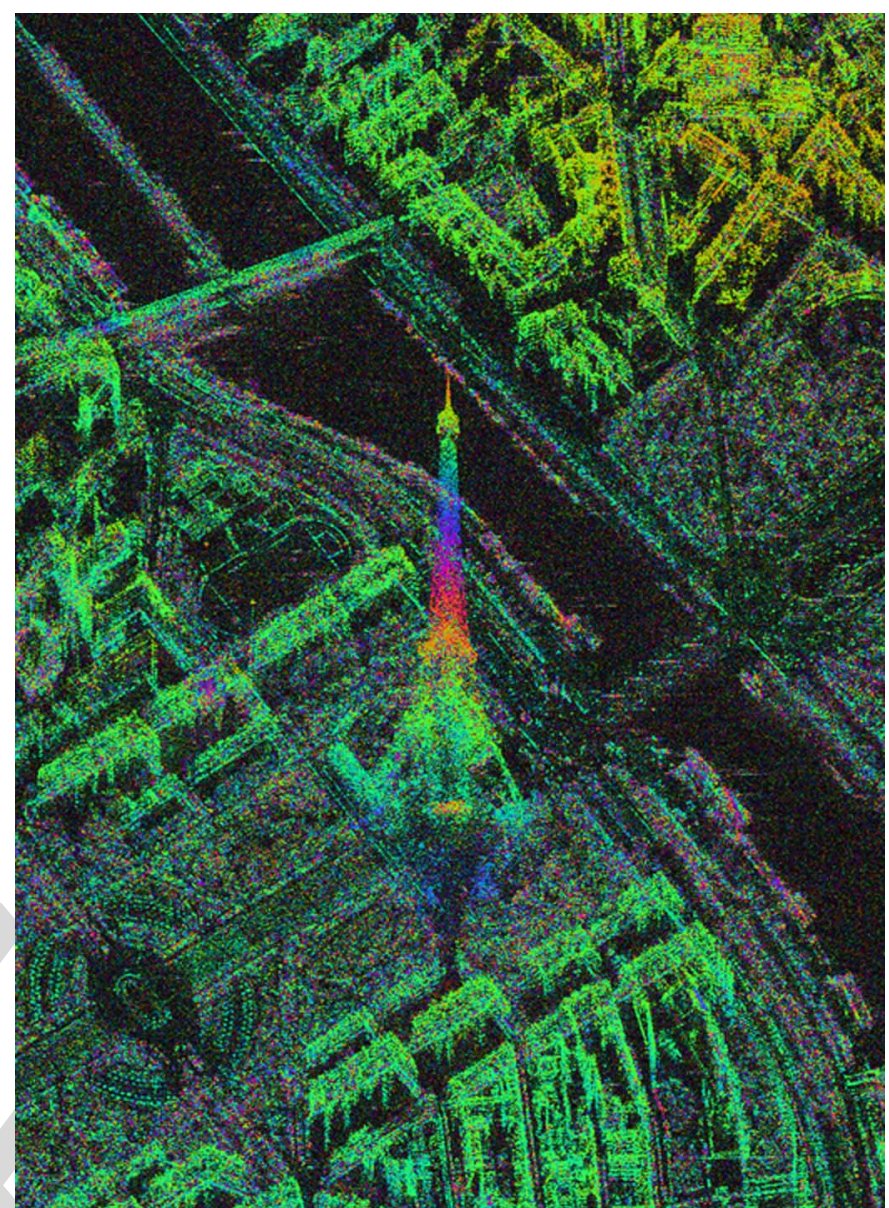

Fig. 12. Zoom into the Eiffel Tower of a high-resolution spotlight interferogram of Paris, France. The images were taken on January 16 and 27, 2008, with a $300-\mathrm{MHz}$ range bandwidth at an incidence angle of $34.7^{\circ}$ and a baseline of $49 \mathrm{~m}$.

inal interferogram features the phase stability over the whole scene without artifacts, the overall coherence in urban builtup areas, and the decorrelation in vegetated park areas after 11 days.

\section{CONCLUSION}

The launch of TerraSAR-X into orbit has been realized for the first time in Germany, an EO project by a PPP with considerable financial contribution by the industry. This enabled an innovative mission to be carried out which could not have been financed otherwise, a mission with a large potential for scientific use, as well as for the sustainable commercialization of EO data.

The mission provides a new class of high-quality X-band SAR products due to its high-resolution capability and the high flexibility of its antenna. In addition, it provides the capability of repeat-pass interferometry. The new DRA mode offers new applications like along-track interferometry and fullpolarimetric data acquisition.

As a next step in Germany's SAR roadmap, DLR and EADS Astrium are currently preparing the TanDEM-X mission [48], [49], scheduled to be launched by the end of 2009. The TanDEM-X mission will feature a second TerraSAR-X-type satellite that will fly in a close formation with TerraSAR-X 


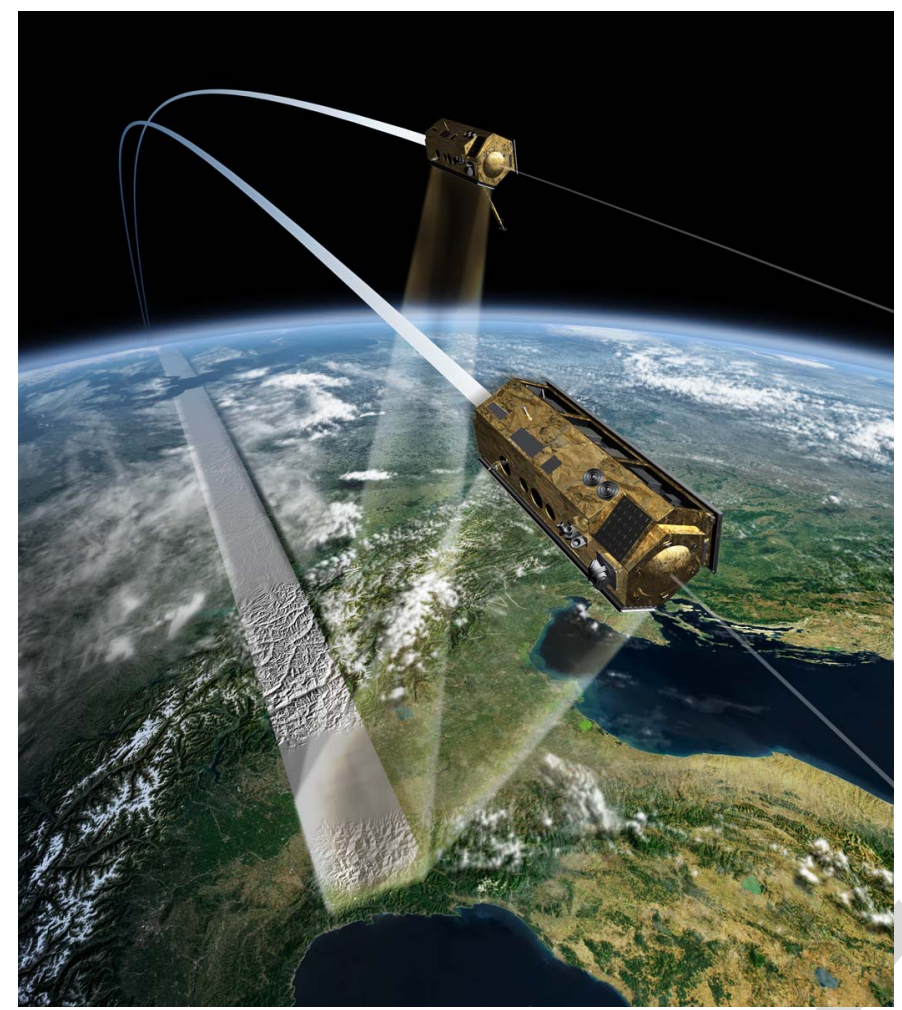

Fig. 13. Artist view of the TerraSAR-X and TanDEM-X satellites flying in close formation. The main goal of the TanDEM-X mission will be the acquisition of a global high-quality DEM with high resolution.

(Fig. 13). The main goal of the TanDEM-X mission will be the acquisition of a global high-quality DEM fulfilling the High-Resolution Terrain Information Level 3 specification. In addition, a new technology development is presently being conducted by DLR, investigating the high-resolution wide-swath concept for a future SAR mission after TanDEM-X, which allows overcoming the restrictions of conventional SAR systems with respect to simultaneously achieved high resolution and wide area coverage [50].

\section{REFERENCES}

[1] R. Werninghaus, S. Buckreuss, and W. Pitz, "TerraSAR-X mission status," in Proc. IEEE IGARSS, Barcelona, Spain, 2007, pp. 3927-3930.

[2] TX-PGS-PL-4001 TerraSAR-X Science Plan2004, Nov. 25.

[3] R. Werninghaus, "TerraSAR-X, a national German radar mission realised in public, private partnership," Q. Bull. Council Eur. Aerosp. Soc., May 10-23, 2008.

[4] S. Buckreuss, R. Werninghaus, and W. Pitz, "The German satellite mission TerraSAR-X," in Proc. IEEE RadarCon, Rome, Italy, 2008, pp. 1-5.

[5] D. Miller and W. Pitz, "The TerraSAR-X satellite," IEEE Trans. Geosci. Remote Sens., vol. 48, no. 2, Feb. 2010, to be published.

[6] B. D. Tapley, S. Bettadpur, M. Watkins, and C. Reigber, "The gravity recovery and climate experiment: Mission overview and early results," Geophys. Res. Lett., vol. 31, no. 9, p. L09 607, May 8, 2004, DOI: 10.1029/2004GL019920.

[7] M. Stangl, R. Werninghaus, and R. Zahn, "The TerraSAR-X active phased array antenna," in Proc. Phased Array, 2003, pp. 70-75.

[8] M. Stangl, R. Werninghaus, B. Schweizer, C. Fischer, M. Brandfass, J. Mittermayer, and H. Breit, "TerraSAR-X technologies and first results," Proc. Inst. Elect. Eng.-Radar, Sonar Navig., vol. 153, no. 2, pp. 86-95, Apr. 2006.

[9] M. Suess, S. Riegger, W. Pitz, and R. Werninghaus, "TerraSAR-XDesign and performance," in Proc. EUSAR, Köln, Germany, 2002.

[10] J. Mittermayer and H. Runge, "Conceptual studies for exploiting the TerraSAR-X dual receive antenna," in Proc. IEEE IGARSS, 2003, pp. 2140-2142.
[11] J. Mittermayer, V. Alberga, S. Buckreuss, and S. Riegger, "TerraSAR-X: Predicted performance," Proc. SPIE, vol. 4881, pp. 244-255, Sep. 22-27, 2002.

[12] R. Lange and B. Smutny, "BPSK laser communication terminals to be verified in space," in Proc. IEEE MILCOM, Oct. 31-Nov. 3, 2004, vol. 1, pp. 441-444.

[13] M. Rothacher, B. D. Tapley, C. Reigber, R. Koenig, C. Falck, L. Grunwaldt, W. Koehler, F.-H. Massmann, and G. Michalak, "The tracking, occultation and ranging (TOR) instrument onboard TerraSAR-X and on TanDEM-X," in Proc. IEEE IGARSS, Jul. 23-28, 2007, pp. 4983-4986.

[14] Y. T. Yoon, M. Eineder, N. Yague-Martinez, and O. Montenbruck, "TerraSAR-X precise trajectory estimation and quality assessment," IEEE Trans. Geosci. Remote Sens., vol. 47, no. 6, pp. 1859-1868, Jun. 2009.

[15] S. Buckreuss and B. Schättler, "The TerraSAR-X ground segment," IEEE Trans. Geosci. Remote Sens., vol. 48, no. 2, Feb. 2010, to be published.

[16] E. Maurer, F. Mrowka, A. Braun, C. Lenzen, Y. Wasser, M. P. Geyer, and M. Wickler, "TerraSAR-X mission planning system: Autonomous command generation for spacecraft operations," IEEE Trans. Geosci. Remote Sens., vol. 48, no. 2, Feb. 2010, to be published.

[17] S. Buckreuss, P. Mühlbauer, J. Mittermayer, W. Balzer, and R. Werninghaus, "The TerraSAR-X ground segment," in Proc. EUSAR, Dresden, Germany, 2006.

[18] U. Steinbrecher, D. Schulze, J. Böer, and J. Mittermayer, "TerraSAR-X instrument operations rooted in the system engineering and calibration project," IEEE Trans. Geosci. Remote Sens., vol. 48, no. 2, Feb. 2010, to be published

[19] B. Bräutigam, J. H. González, M. Schwerdt, and M. Bachmann, "TerraSAR-X instrument calibration results and extension for TanDEM-X," IEEE Trans. Geosci. Remote Sens., vol. 48, no. 2, Feb. 2010, to be published.

[20] J. Mittermayer, B. Schättler, and M. Younis, "TerraSAR-X commissioning phase execution summary," IEEE Trans. Geosci. Remote Sens., vol. 48, no. 2, Feb. 2010, to be published.

[21] J. Mittermayer, B. Schättler, and M. Younis, "TerraSAR-X commissioning phase execution and results," in Proc. IEEE IGARSS, Boston, MA, 2008, pp. II-197-II-200.

[22] J. Mittermayer, M. Younis, B. Bräutigam, T. Fritz, R. Kahle, and R. Metzig, "Verification of TerraSAR-X system," in Proc. IEEE IGARSS, Barcelona, Spain, 2007, pp. 4929-4932.

[23] R. Metzig, B. Bräutigam, D. Polimeni, J. Böer, M. Bachmann, and J. Mittermayer, "TerraSAR-X instrument characterization/verification," in Proc. 7th Eur. Conf. Synthetic Aperture Radar, Friedrichshafen, Germany, 2008.

[24] J. Mittermayer, U. Steinbrecher, A. Meta, N. Tous-Ramon, S. Wollstadt, M. Younis, J. Marquez, D. Schulze, and C. Ortega, "TerraSAR-X system performance and command generation," in Proc. 7th Eur. Conf. Synthetic Aperture Radar, Friedrichshafen, Germany, 2008.

[25] J. Marquez-Martinez, C. Gonzalez, M. Younis, S. Wollstadt, R. Metzig, U. Steinbrecher, N. Tous-Ramon, A. Meta, and J. Mittermayer, "In-orbit SAR performance of TerraSAR-X," in Proc. IEEE IGARSS, Barcelona, Spain, 2007, p. 3931.

[26] J. Mittermayer, M. Younis, R. Metzig, S. Wollstadt, J. Márquez, and A. Meta, "TerraSAR-X system performance characterization and verification," IEEE Trans. Geosci. Remote Sens., vol. 48, no. 2, Feb. 2010, to be published.

[27] M. Schwerdt, B. Bräutigam, M. Bachmann, and B. Döring, "TerraSAR-X calibration-First results," in Proc. IEEE IGARSS, Barcelona, Spain, 2007, pp. 3932-3935.

[28] M. Schwerdt, B. Bräutigam, B. Döring, D. Schrank, and J. H. Gonzalez, "Final results of the efficient TerraSAR-X calibration method," in Proc. Radarcon, Rome, Italy, 2008, pp. 1-6.

[29] M. Bachmann, M. Schwerdt, and B. Bräutigam, "TerraSAR-X antenna calibration and monitoring based on a precise antenna model," IEEE Trans. Geosci. Remote Sens., vol. 48, no. 2, Feb. 2010, to be published.

[30] T. Fritz, H. Breit, B. Schättler, U. Balss, M. Lachaise, and M. Eineder, "TerraSAR-X image products: Characterization and verification," in Proc. EUSAR Conf., Friedrichshafen, Germany, 2008.

[31] E. Mikusch, M. Wolfmüller, E. Diedrich, D. Dietrich, and M. Böttcher, "Management of 'future products' in the distributed payload ground segment for TerraSAR-X," in Proc. DASIA, 2003, p. 11.1.

[32] M. Wickler, A. Braun, and M. Geyer, "A strategic mission planning concept for TerraSAR-X," in Proc. 8th Int. Symp. Space Mission Oper. Ground Data Syst., Montreal, QC, Canada, 2004.

[33] H. Breit, T. Fritz, B. Schättler, E. Börner, M. Lachaise, A. Niedermeier, M. Eineder, and U. Balss, "TerraSAR-X payload data processing-First experiences," in Proc. IEEE IGARSS, Barcelona, Spain, 2007, p. 3936. 
[34] B. Schättler, T. Fritz, H. Breit, N. Adam, U. Balss, M. Lachaise, M. Eineder, and A. Niedermeier, "TerraSAR-X SAR data processing from commissioning and early orbit phase," in Proc. EARSeL Joint Workshop Remote Sens., New Challenges High Resolution, Bochum, Germany, 2008.

[35] M. Eineder, N. Adam, R. Bamler, N. Yague-Martinez, and H. Breit, "TerraSAR-X spotlight SAR interferometry," IEEE Trans. Geosci. Remote Sens., vol. 47, no. 5, pp. 1524-1535, May 2009.

[36] S. Suchandt, H. Runge, M. Eineder, H. Breit, A. Kotenkov, and U. Balss, "First results of ground moving target analysis in TerraSAR-X data," in Proc. IEEE IGARSS, Barcelona, Spain, 2007, p. 3943.

[37] F. D. Zan and A. M. Guarnieri, "TOPSAR: Terrain observation by progressive scan," IEEE Trans. Geosci. Remote Sens., vol. 44, no. 9, pp. 2352-2360, Sep. 2006.

[38] A. Meta, J. Mittermayer, U. Steinbrecher, and P. Prats, "Investigations on the TOPSAR acquisition mode with TerraSAR-X," in Proc. IEEE IGARSS, Barcelona, Spain, 2007, pp. 152-155.

[39] A. Meta, P. Prats, U. Steinbrecher, J. Mittermayer, and R. Scheiber, "TerraSAR-X TOPSAR and ScanSAR comparison," in Proc. EUSAR Conf. TerraSAR- $X$ Image Products, Charact. Verification, Friedrichshafen, Germany, 2008.

[40] P. Prats, R. Scheiber, J. Mittermayer, A. Meta, and A. Moreira, "Processing of sliding spotlight and TOPS SAR data using baseband azimuth scaling," IEEE Trans. Geosci. Remote Sens., vol. 48, no. 2, Feb. 2010, to be published.

[41] J. Mittermayer, P. Prats, R. Scheiber, and U. Steinbrecher, "TOPS imaging with TerraSAR-X: Mode design and performance analysis," IEEE Trans. Geosci. Remote Sens., vol. 48, no. 2, Feb. 2010, to be published.

[42] H. Fiedler, E. Boerner, J. Mittermayer, and G. Krieger, "Total zero Doppler steering-A new method for minimizing the Doppler centroid," IEEE Geosci. Remote Sens. Lett., vol. 2, no. 2, pp. 141-145, Apr. 2005

[43] S. Lehner, J. Schulz-Stellenfleth, and S. Brusch, "TerraSAR-X measurements of wind fields, ocean waves and currents," in Proc. SEASAR, Jan. 21-25, 2008. DVD: SP-565, ESA, Frascati, Italy.

[44] Center for Satellite Based Crisis Information. [Online]. Available: http://www.zki.caf.dlr.de/

[45] H. Breit, T. Fritz, U. Balss, A. Niedermeier, M. Lachaise, and M. Vonavka, "TerraSAR-X SAR processing and products," IEEE Trans. Geosci. Remote Sens., vol. 48, no. 2, Feb. 2010, to be published.

[46] S. Suchandt, H. Runge, H. Breit, U. Steinbrecher, A. Kotenkov, and U. Balss, "Automatic extraction of traffic flows using TerraSAR-X along-track interferometry," IEEE Trans. Geosci. Remote Sens., vol. 48, no. 2, Feb. 2010, to be published.

[47] M. Eineder, N. Adam, R. Bamler, N. Yague-Martinez, and H. Breit, "Spaceborne spotlight SAR interferometry with TerraSAR-X," IEEE Trans. Geosci. Remote Sens., vol. 47, no. 5, pp. 1524-1535, May 2009.
[48] M. Bartusch, H. Berg, and O. Siebertz, "The TanDEM-X mission," in Proc. EUSAR Conf., Friedrichshafen, Germany, 2008.

[49] G. Krieger, A. Moreira, H. Fiedler, I. Hajnsek, M. Werner, M. Younis, and M. Zink, "A satellite formation for high-resolution SAR interferometry," IEEE Trans. Geosci. Remote Sens., vol. 45, no. 11, pp. 3317-3341, Nov. 2007.

[50] C. Fischer, C. Heer, G. Krieger, and R. Werninghaus, "A high resolution wide swath SAR," in Proc. EUSAR, Dresden, Germany.

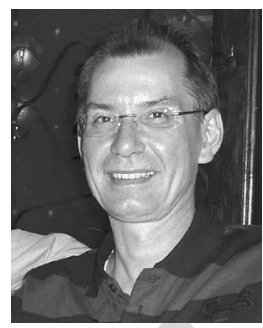

Rolf Werninghaus received the Dipl.Ing. degree in physics technology engineering from the Fachhochschule Hagen, Hagen, Germany, in 1980 and the M.Sc. in physics from the University of Dortmund, Dortmund, Germany, in 1988.

Since 1988, he has been with the German Aerospace Center (DLR), Bonn, Germany, where he started as a Project Engineer for the first SIR-C/ $\mathrm{X}-\mathrm{SAR}$ mission with the Project Management Department, Space Agency, and was the Project Manager for the second SIR-C/X-SAR mission on the NASA Space Shuttle from 1994 to 1996. Between 1996 and 2000, he was the Program Manager for the Shuttle Radar Topography Mission. In mid-2000, he was the TerraSAR-X Project Manager. Since 2007, he has been the Group Leader for the Earth Observation projects and missions with the German Space Agency.

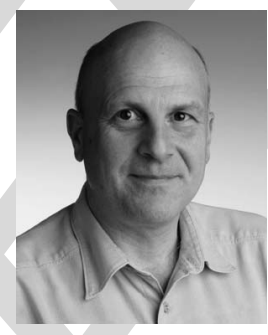

Stefan Buckreuss received the Dipl.Ing. degree in electronics from the Technical University of Munich, Munich, Germany, in 1988 and the Dr.Ing. degree from the University of Stuttgart, Stuttgart, Germany, in 1994.

Since 1988, he has been with the Microwaves and Radar Institute, German Aerospace Center (DLR), Wessling, Germany, where he gained broad experience in SAR signal processing and motion compensation, antijamming, and interferometry for DLR's airborne SAR system E-SAR. Within the scope of the international SRTM/X-SAR mission, he developed the online radar data analysis and quicklook processing tools for the X-SAR sensor. In 2002, he was engaged in the German TerraSAR-X mission, where he was responsible for the development of the instrument operations and calibration segment until he was assigned the role of Ground Segment Integration Manager. He is currently the TerraSAR-X Mission Manager and Designated Mission Manager for TanDEM-X. 


\title{
The TerraSAR-X Mission and System Design
}

\author{
Rolf Werninghaus and Stefan Buckreuss
}

\begin{abstract}
This paper describes the TerraSAR-X mission concept within the context of a public-private partnership (PPP) agreement between the German Aerospace Center (DLR) and the industry. It briefly describes the PPP concept as well as the overall project organization. This paper then gives an overview of the satellite design and the corresponding ground segment, as well as the main mission parameters. After a short introduction to the scientific and commercial exploitation scheme, this paper finally focuses on the mission accomplishments achieved so far during the ongoing mission.
\end{abstract}

Index Terms - Ground segment, radar, satellite, scientific and commercial exploitation, system design, TerraSAR-X.

\section{INTRODUCTION}

O N JUNE 15, 2007, Germany's first operational radar satellite TerraSAR-X was launched into orbit. This event marked the culmination point of a long and successful synthetic aperture radar (SAR) technology development line, which has been initiated and supported by the German Aerospace Center (DLR) together with the German industry since the late 1970s.

TerraSAR-X is Germany's first national remote sensing satellite being implemented in a public-private partnership (PPP) between DLR and EADS Astrium GmbH. TerraSAR-X supplies high-quality radar data for purposes of scientific observation of the Earth for a period of at least five years. At the same time, it is designed to satisfy the steadily growing demand of the private sector for remote sensing data in the commercial market.

The TerraSAR-X mission [1] is the continuation of the scientifically and technologically successful radar missions X-SAR and the Shuttle Radar Topography Mission, which have been conducted in cooperation with the National Aeronautics and Space Administration and the Italian Space Agency (ASI) in 1994 and 2000. In parallel to these missions, the national technology developments DESA (X-band SAR antenna demonstrator) and TOPAS (technology development for onboard SAR processing and storage demonstrator) have been brought forward, which have prepared the floor for the national implementation of a complex SAR mission like TerraSAR-X.

Today, remote sensing data and the derived information products about the Earth are needed not only for scientific purposes but also for a variety of private business applications. Therefore, TerraSAR-X aims to hand over the acquisition of

Manuscript received February 27, 2009; revised June 18, 2009.

R. Werninghaus is with the Earth Observation Department, German Space Agency, German Aerospace Center (DLR), 53227 Bonn, Germany (e-mail: rolf.werninghaus@dlr.de).

S. Buckreuss is with the Microwaves and Radar Institute, German Aerospace Center (DLR), 82234 Wessling, Germany (e-mail: stefan.buckreuss@dlr.de).

Color versions of one or more of the figures in this paper are available online at http://ieeexplore.ieee.org.

Digital Object Identifier 10.1109/TGRS.2009.2031062 such data to the private sector in the long run, turning it into a self-supporting sustainable business.

In this context, TerraSAR-X serves two main goals: The first goal is to provide the scientific community with multimode X-band SAR data. The broad spectrum of scientific application areas includes hydrology, geology, climatology, oceanography, environmental monitoring, and disaster monitoring, as well as cartography (digital elevation model (DEM) generation) and interferometry [2]. Representing the federal government, DLR will be the sole owner of the TerraSAR-X data and coordinates their scientific utilization.

The second goal is the establishment of a commercial Earth observation (EO) market in Europe, i.e., the development of a sustainable EO business so that follow-on systems can completely be financed by the industry from the profit. Taking into account the expected business development, the PPP agreement is aiming at the following:

1) the self-sustainability of the business;

2) the implementation and operation of a follow-on system TerraSAR-X2 by the industry;

3) the scientific exploitation rights for DLR for TerraSAR-X2.

If the business develops as foreseen today, EADS Astrium $\mathrm{GmbH}$ will finance a follow-on system after the satellite's service life has ended, thus securing the continuity of the business.

\section{PRoJECT ORGANIZATION}

\section{A. Public-Private Partnership}

TerraSAR-X is the first space project in Germany that has been realized in a PPP, with considerable financial contribution by the industry [3]. The partnership model is based on a cooperation agreement that was signed by DLR and EADS Astrium $\mathrm{GmbH}$ on March 25, 2002. The objective is for equal partners to cooperate, with each making an equitable contribution toward a joint project in order to meet their own needs. Going beyond the traditional process of awarding government-funded contracts, this approach is based on a cooperative project management. Having different objectives, both sides contribute their resources, jointly implementing the project and utilizing its results afterward. The advantage of this approach is that it permits meeting scientific goals while supporting industrial marketing needs at the same time. In this way, investments are secured which a single partner would be unable to provide on its own.

Under the partnership agreement, EADS Astrium GmbH has been awarded a contract by DLR to develop, build, and launch the satellite. For its part, DLR developed the corresponding ground segment as described in Section III-C. DLR has also set up the science service segment and took over the responsibility 


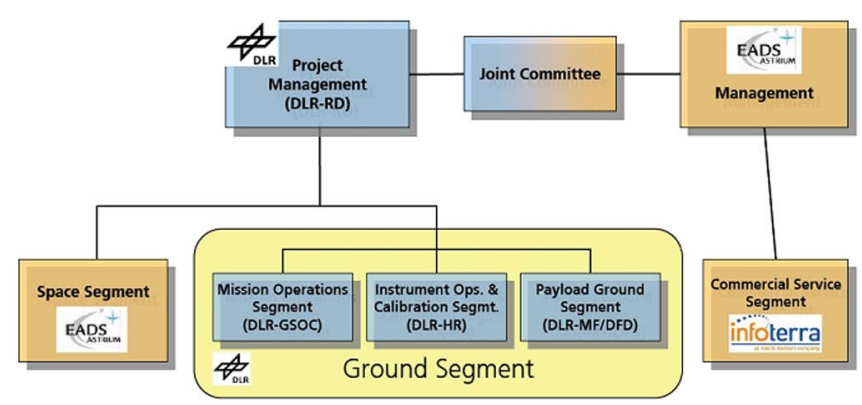

Fig. 1. Block diagram of the TerraSAR-X project structure with its governing body of the Joint Committee, as well as the three main elements space, ground, and service segment.

to provide data to the science community as explained in Section IV. In addition, DLR is responsible for the operation of the satellite over a period of five years.

EADS Astrium undertook to set up a distribution system and commercialize the TerraSAR-X data and products through its fully owned subsidiary Infoterra $\mathrm{GmbH}$. In return for the exclusive right to commercialize the TerraSAR-X data, EADS Astrium $\mathrm{GmbH}$ agreed to contribute to the development cost of the satellite. In addition, EADS Astrium contributed with a sales-dependent share of the operating cost for the satellite during its operational phase and invested considerable sums in marketing the satellite's data and products.

\section{B. Project Structure}

The overall project management for the TerraSAR-X project is located in the directorate for space projects (DLR-RD) in Bonn, as shown in Fig. 1. Under contract to DLR, EADS Astrium $\mathrm{GmbH}$ in Friedrichshafen, Germany, has developed the TerraSAR-X satellite, whereas the DLR institutes in Oberpfaffenhofen provided the related ground segment.

Within this context, DLR has the following responsibilities:

1) overall project management;

2) management of the TerraSAR-X contract with Astrium;

3) mission management;

4) science coordination;

5) development of the ground segment;

6) system engineering, calibration/verification;

7) satellite and instrument operations (German Space Operation Center (GSOC): Weilheim station);

8) data reception (Neustrelitz), processing, archiving, and distribution.

EADS Astrium/Infoterra, on the other hand, was in charge of the development, assembly, and launch of the TerraSAR-X satellite (as contractor to DLR), as well as of the businessrelated activities like the following:

1) X-band-based product research and development;

2) X-band-based market development;

3) development of a commercial service segment;

4) commercial exploitation of the TerraSAR- $X$ data;

5) implementation and operation of a follow-on system TerraSAR-X2.

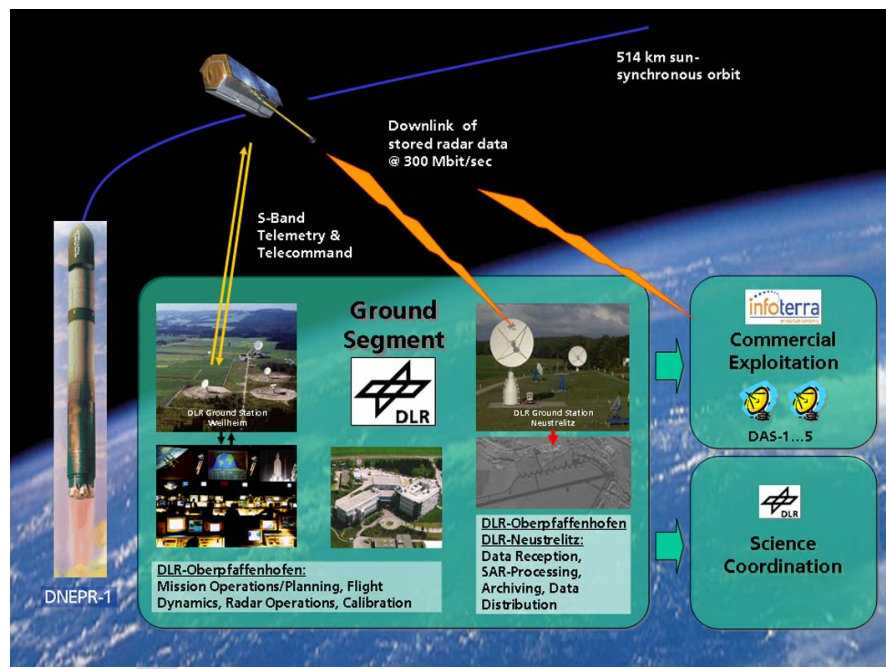

Fig. 2. General TerraSAR-X mission concept showing the command and data streams from/to the Mission Control Center in Oberpfaffenhofen and the DLR ground stations in Weilheim and Neustrelitz, as well as the Infoterra DAS of commercial customers and the science user community represented by the science coordinator.

\section{Mission AND System Design}

\section{A. Mission Design}

The TerraSAR-X satellite [4] was launched from Baikonur on a Russian/Ukrainian Dnepr-1 launch vehicle with a $1.5-\mathrm{m}-$ long fairing extension. A sun-synchronous dawn-dusk orbit with an 11-day repeat period was selected as a good compromise between radar performance, order to-acquisition time, and revisit time. Once in the orbit, the satellite has been taken over by the Mission Control Center in Oberpfaffenhofen. The system baseline includes two ground stations in Germany. Weilheim is used as the satellite control station, and Neustrelitz serves as the central receiving station for the $300-\mathrm{Mb} / \mathrm{s} \mathrm{X}$-band downlink (Fig. 2). Beyond that up to now, five additional direct access stations (DAS) - receiving stations of commercial partners of Infoterra $\mathrm{GmbH}$ - have been set up to extend the baseline receiving station concept [1]. More DAS may be added in the future.

\section{B. TerraSAR-X Satellite}

The TerraSAR-X satellite bus (see also the related TGRS article [5] in this Special Issue) is a heritage from the successful CHAMP and GRACE missions [6]. The satellite configuration of TerraSAR-X is shown in Fig. 3. TerraSAR-X features an advanced high-resolution X-band SAR based on the active phased array technology [7], [8] which allows the operation in spotlight, stripmap, and ScanSAR mode with two polarizations in various combinations (see Table I). It combines the ability to acquire high-resolution images for detailed analysis, as well as wide-swath images for overview applications [9]. The experimental dual-receive antenna (DRA) mode [10] allows receiving independently the echoes from the two azimuth antenna halves. This new experimental mode enables the use of interesting new features like along-track interferometry, full-polarimetric data acquisition, and the enhancement of stripmap azimuth resolution [11]. 


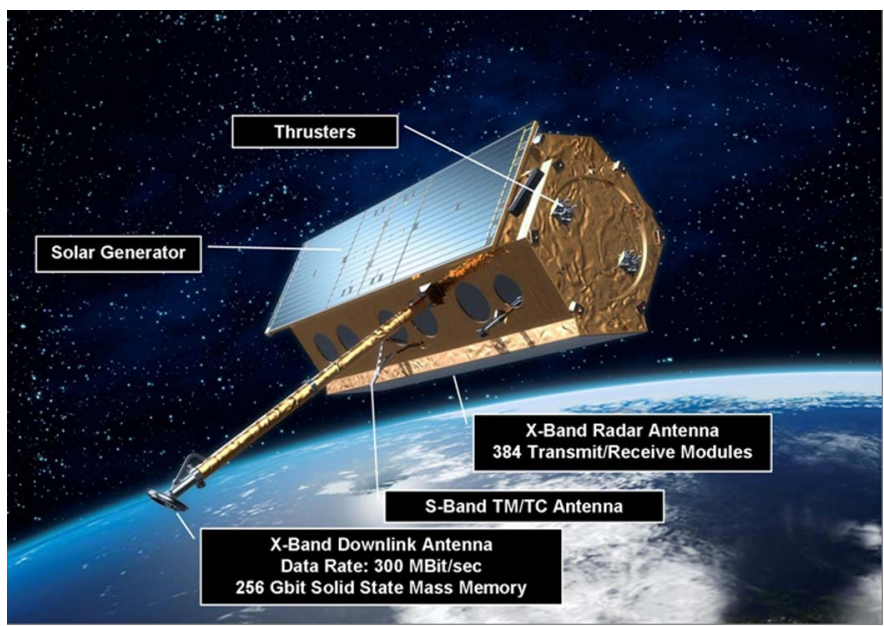

Fig. 3. Artist view of the TerraSAR-X satellite. Note the (upper left) solar generator, the (lower left) boom with the X-band downlink antenna, and the (lower right) $\mathrm{X}$-band radar antenna.

TABLE I

Main TERraSAR-X System Parameters

\begin{tabular}{|c|c|}
\hline Height: & $4.88 \mathrm{~m}$ \\
\hline Width: & $2.4 \mathrm{~m}$ \\
\hline Launch Mass: & $\begin{array}{l}1.230 \mathrm{~kg} \\
\text { (including payload mass } 400 \mathrm{~kg} \text { ) }\end{array}$ \\
\hline Orbit height: & $514 \mathrm{~km}$ \\
\hline Inclination: & $97.4^{\circ}$, sun-synchronous \\
\hline Orbit tube: & $250 \mathrm{~m}$ radius \\
\hline $\begin{array}{l}\text { Orbit maintenance } \\
\text { frequency: }\end{array}$ & $\begin{array}{l}\text { between } 1 / \text { week and } 1 / \text { day } \\
\text { (depending on solar activity) }\end{array}$ \\
\hline $\begin{array}{l}\text { Orbit determination } \\
\text { accuracy: }\end{array}$ & $\begin{array}{l}\text { better than } 20 \mathrm{~cm} \\
\text { (with 2-frequency GPS) }\end{array}$ \\
\hline Imaging capability: & up to $300 \mathrm{sec} /$ orbit \\
\hline Launcher: & Dnepr-1 (former SS-18) \\
\hline Launch: & $\begin{array}{l}15 \text { June } 2007,4: 14 \text { h (CEST) } \\
\text { From Baikonur, Kazakhstan }\end{array}$ \\
\hline Life time: & $\begin{array}{l}5 \text { years } \\
\text { (consumables up to } 7 \text { years) }\end{array}$ \\
\hline Radar frequency: & $9.65 \mathrm{GHz}$ \\
\hline Transmit bandwidth: & $\begin{array}{l}5 \ldots . .150 \mathrm{MHz} \text { nominal } \\
300 \mathrm{MHz} \text { experimental }\end{array}$ \\
\hline Polarization: & $\mathrm{HH} / \mathrm{VV} / \mathrm{HV} / \mathrm{VH}$ \\
\hline $\begin{array}{l}\text { Stripmap Mode: } \\
\text { [Range x Azimuth] }\end{array}$ & $\begin{array}{l}\text { Resolution: } 3 \mathrm{~m} \text { x } 3 \mathrm{~m} \\
\text { Scene Size: } 30 \mathrm{~km} \text { x } 50 \mathrm{~km}\end{array}$ \\
\hline $\begin{array}{l}\text { Spotlight Mode: } \\
\text { [Range x Azimuth] }\end{array}$ & $\begin{array}{l}\text { Resolution: } 1 \mathrm{~m} \times 1.5 \mathrm{~m} \ldots 3.5 \mathrm{~m} \\
\text { Scene Size: } 10 \mathrm{~km} \times 5 \mathrm{~km} \ldots 10 \mathrm{~km}\end{array}$ \\
\hline $\begin{array}{l}\text { ScanSAR Mode: } \\
\text { [Range } x \text { Azimuth] }\end{array}$ & $\begin{array}{l}\text { Resolution: } 16 \mathrm{~m} \text { x } 16 \mathrm{~m} \\
\text { Scene Size: } 100 \mathrm{~km} \text { x } 150 \mathrm{~km}\end{array}$ \\
\hline
\end{tabular}

In addition to the SAR instrument, two secondary payloads fly on the TerraSAR-X spacecraft:

1) the laser communication terminal (LCT), a technology demonstrator for an intersatellite communication link developed by TESAT, Backnang, in contract to DLR, allowing for a $5.6-\mathrm{Gb} / \mathrm{s}$ satellite-to-satellite or satelliteto-ground communication link [12];

2) the tracking, occultation, and ranging (TOR) instrument package, a dual-frequency GPS tracking receiver and a laser reflector set for high-precision orbit determination and occultation measurements provided by the GeoForschungsZentrum Potsdam and the University of Texas Center for Space Research [13]. As shown in
Table I, TOR allows for a high-precision orbit determination accuracy of better than $20 \mathrm{~cm}$ [14].

\section{TerraSAR-X Ground Segment}

The TerraSAR-X ground segment (see also the related TGRS articles [15] and [16] in this Special Issue) is the central element for controlling and operating the TerraSAR-X satellite, for calibrating its SAR instrument, and for archiving the SAR data, as well as generating and distributing the basic data products. The overall TerraSAR-X ground infrastructure consists of two major parts:

1) the DLR-provided ground segment;

2) the commercial exploitation and service segment (TSXX) developed by Infoterra.

The DLR ground segment is based on an existing national infrastructure as much as possible and was optimized for flexible response to (scientific and commercial) user requests and fast image product turnaround times. It is composed of three major elements [17]:

1) the mission operations segment provided by GSOC for control of the satellite;

2) the instrument operation and calibration segment (see also the related TGRS articles [18] and [19] in this Special Issue) provided by the Microwaves and Radar Institute (IHR);

3) the payload ground segment for receiving, processing, archiving, calibrating, and distributing the radar data provided by the German Remote Sensing Data Center (DFD) and the DLR Remote Sensing Technology Institute (IMF).

\section{SCIENTIFIC COORDINATION AND COMMERCIAL EXPLOITATION}

TerraSAR-X is an operational SAR system for scientific and commercial applications. The commercial exploitation is exclusively granted to Astrium/Infoterra $\mathrm{GmbH}$.

DLR is responsible for the scientific utilization of the TerraSAR-X products. The status "scientific use" needs to be gained via a selection process. The Science Service System (http://sss.terrasar-x.dlr.de/) was developed for this purpose. Already prior to the launch of the TerraSAR-X satellite, a prelaunch announcement of opportunity (AO) was issued by DLR. Since the end of October 2007, new proposals can be submitted under a general $\mathrm{AO}$ at any time. Under these AOs, more than 300 scientific proposals have been accepted until mid-2009, resulting in several thousands of data acquisition requests. The corresponding TerraSAR-X data are provided to the costs of fulfilling the user request. Additional AOs are planned, where special conditions might be applied with respect to the data provision.

The relative number of proposals from the AOs in different application fields is shown in Fig. 4. As expected, the "land cover and vegetation" area is the most significant application field, as the TerraSAR-X mission has been particularly designed for land applications. Within this subgroup, there is a relatively equal distribution between urban, forest, agriculture, 


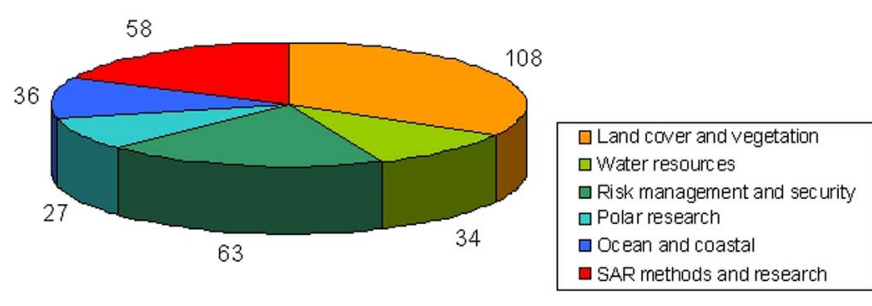

Fig. 4. Under the TerraSAR-X AOs, more than 300 scientific proposals have been accepted until mid-2009. The figure shows the relative distribution of these proposals in the different application areas.

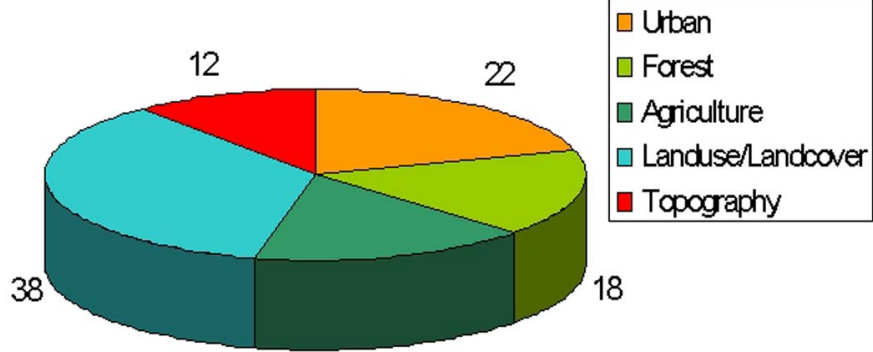

18

Fig. 5. Relative distribution of the 108 proposals in the land cover and vegetation application area in Fig. 4. Among these, the land use/land cover is the most significant field of use.

topography, and land use/land cover application areas, with the latter being the most significant field of use, as can be seen in Fig. 5.

Commercial customers, on the other hand, will have to contact Infoterra (http://www.terrasar.com/) for access to the TerraSAR-X data via the commercial TerraSAR-X exploitation and service infrastructure (TSXX) developed by Infoterra. In addition to the baseline station in Neustrelitz, Infoterra sets up additional receiving stations for dedicated commercial customers, which require fast and direct access to the TerraSAR-X data. These so-called DAS are implemented to extend the baseline receiving station concept.

\section{Mission ACCOMPLishments}

TerraSAR-X was successfully launched on June 15, 2007, 2:14 UTC, on Dnepr-1 in Baikonur, Kasachstan. During the following launch and early orbit phase (LEOP), the basic functionalities of the bus and the prime and secondary payload were checked out.

The first acquisition of the satellite telemetry occurred 15 min after launch over the European Space Agency ground station in Malindi, Kenya. Throughout the following days, the satellite systems and radar instrument were switched on and are working well since then. The $\mathrm{X}$-band data reception was switched on at LEOP day 4. The radar performance is excellent; the first image was processed already at LEOP day 5 on June 19, 2007. In the following days, all standard imaging modes (stripmap, spotlight, and ScanSAR) have been exercised successfully.

The checking out of the dual-frequency GPS receiver IGOR (secondary payload) and the LCT (secondary payload) was

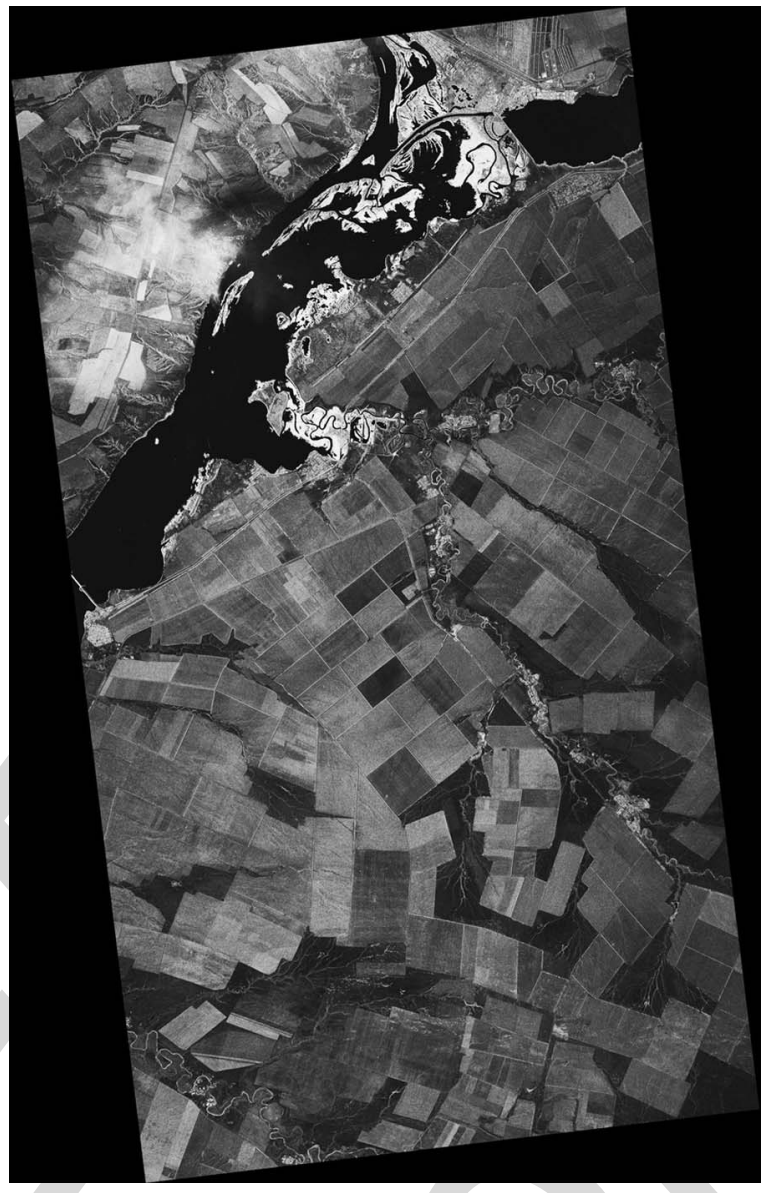

Fig. 6. First TerraSAR-X image, showing a $30 \mathrm{~km} \times 60 \mathrm{~km}$ area in Russia, western to Wolgograd. The scene has been imaged in the stripmap mode, $\mathrm{HH}$ polarization, on June 19, 2007. The resolution is approximately $15 \mathrm{~m}$.

completed as planned. The first satellite-to-satellite communication links between the TerraSAR-X LCT and the U.S. NFIRE satellite were executed successfully in the following months.

Fig. 6 shows the first image acquired by TerraSAR-X. The image shows a $30 \mathrm{~km} \times 60 \mathrm{~km}$ area in Russia, western to Wolgograd, which has been imaged in the stripmap mode with $\mathrm{HH}$ polarization. The resolution is approximately $15 \mathrm{~m}$.

In the upper half of the image, the Tsimlyanskoye reservoir can be seen. Here, the River Don is dammed with the water being used for power generation. In the immediate neighborhood, the meandering oxbow river bends can be seen as dark surfaces. Calm water surfaces are typically very dark in radar photographs since the radar radiation hitting them is reflected away. In the center left of the image, a railway bridge crosses the River Don with the railway line disappearing toward the northeast. In the lower half, large agricultural areas dominate. The different brightness of the fields results from the differing vegetation and the particular stages of their annual growth cycles.

During this survey, a thick cloud cover prevailed. Nevertheless, radar satellites such as TerraSAR-X offer imaging capability even in the case of cloudy skies and at night. However, exceptional strong precipitation events like heavy thunderstorms may influence even radar imaging. Such an event can be seen at the upper left part of the radar image as a bright "veil." 
The successful processing of this first image demonstrated the functional capability of the satellite on the one hand and the operability of the ground segment on the other hand. The entire processing chain, including order input, scheduling, commanding, data acquisition, on-ground data reception, SAR processing, and archiving of the images, has been verified. This result was also the consequence of a comprehensive prelaunch testing program, including numerous space-to-ground-segment tests.

After the successful completion of the LEOP, the commissioning phase (see also the related TGRS article [20] in this Special Issue) was started on June 22, 2007, encompassing an ambitious program with respect to the following goals [21]:

1) orbit and attitude verification [22];

2) instrument characterization/verification [23], [24];

3) overall SAR system performance characterization [21], [25] (see also the related TGRS article [26] in this Special Issue);

4) calibration of the radar data [27], [28];

a) geometric calibration;

b) antenna pointing calibration;

c) antenna model verification (see also the related TGRS article [29] in this Special Issue);

d) relative radiometric calibration;

e) absolute radiometric calibration;

f) internal instrument calibration.

5) checking out of the receiving station and processing system;

6) SAR product verification [30];

7) checking out of the DAS operated by Infoterra $\mathrm{GmbH}$;

8) load tests including the commercial service segment [31], [32];

9) interferometric processing [33], [34].

The commissioning phase was finished right on schedule after 5.5 months, and the goal was attained to ensure optimum SAR product quality and to accomplish the full operational readiness of the space and ground segment in December 2007. The TerraSAR-X team executed a very comprehensive calibration and verification program. During the commissioning phase, 12000 data takes were executed, and all imaging modes were tested and verified. In several cases, the obtained results even exceeded the initial specifications. Consequently, TerraSAR-X turned out to be a very stable precision instrument for radar imaging.

Furthermore, the potential of TerraSAR-X for repeat pass [35], as well as along-track interferometry [36] and TOPSAR [37]-[39], was shown (see also the related articles [40] and [41] in this TGRS Special Issue). Novel techniques such as the total zero Doppler steering proved their effectivity [42]. The benefit from the high resolution provided by TerraSAR-X was demonstrated for geoscientific applications, oceanography [43], and disaster monitoring [44].

Consequently, the operational phase could be kicked off on January 7, 2008, and the image production for scientific and commercial users is running extremely satisfactory since then. In the first two years of the mission, approximately 35000 data takes have been acquired by the satellite, relating to approximately 50000 data products, with a still growing trend.

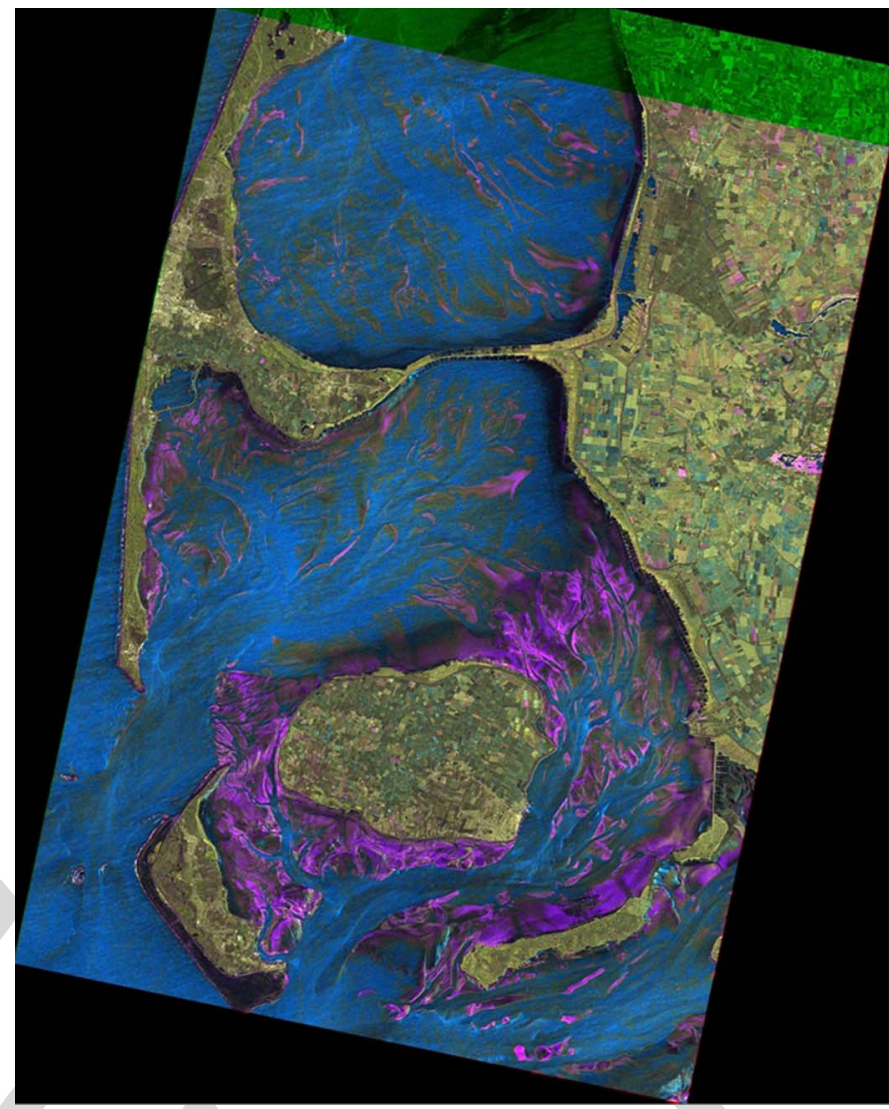

Fig. 7. Multitemporal TerraSAR-X image of mudflats near the island of Sylt, Germany. The image is a combination of two acquisitions that were taken by TerraSAR-X in April and May 2008 in stripmap mode. The individual pictures are colored red and green, respectively.

\section{EXAMPLE IMAGERY}

In the following, a few examples of TerraSAR-X imagery shall demonstrate the high quality of the data products (see also the related TGRS article [45] in this Special Issue).

The first example (Fig. 7) shows the mudflats near the island of Sylt, Germany. It was compiled from two images that were taken by TerraSAR-X in April and May 2008 in stripmap mode. The individual pictures are colored red and green, respectively. The difference in the reflected radar signals (in blue) is particularly large over the areas of water, where the most changes occurred in between the two data takes. The resulting image can be used to extensively study the morphology, sediments, and habitats in the Wadden Sea. Structures such as tidal creek courses (recognizable in the blue area) and mussel beds (light areas near the coast) are clearly shown.

The high-resolution capability of advanced radar sensors like TerraSAR-X opens up new observation opportunities particularly in urban areas. The following example (Fig. 8) shows an image of the Tokyo river island taken on March 7, 2008, in high-resolution spotlight mode with HH polarization. Due to the high resolution of the TerraSAR-X image, the details of the urban scenery, including the skyscrapers at the river shoreline, can clearly be distinguished. The small inlay in the image shows the appearance of the same scene in a Google Earth image for comparison. Note that the 3-D appearance of the towers in the 


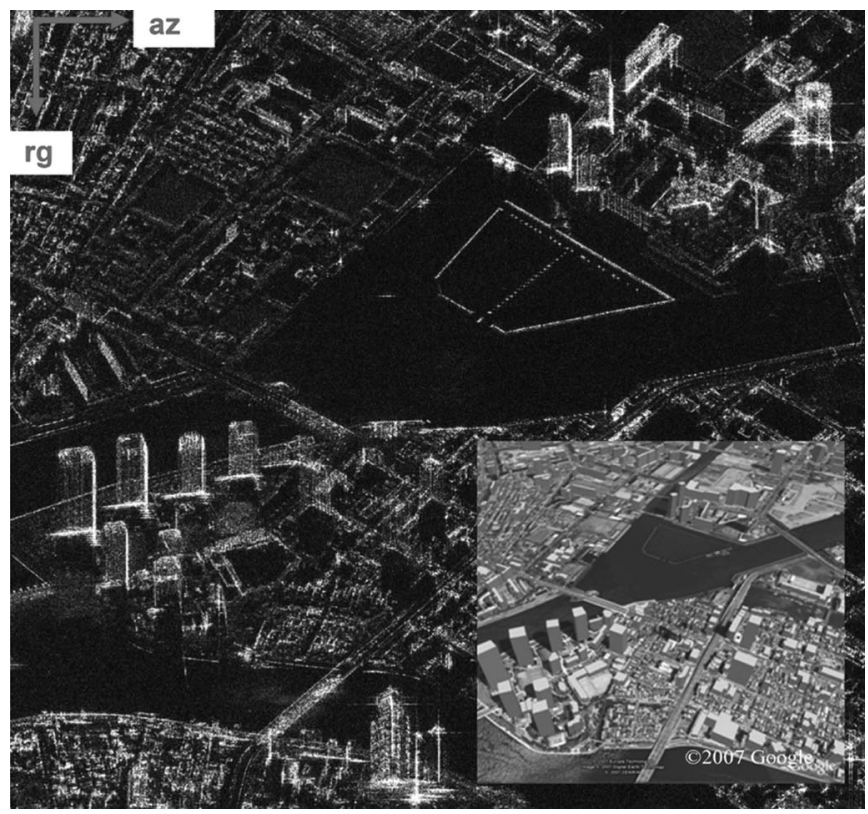

Fig. 8. High-resolution spotlight image of the Tokyo river island taken on March 7, 2008, in HH polarization with a small Google Earth image inlay for comparison.

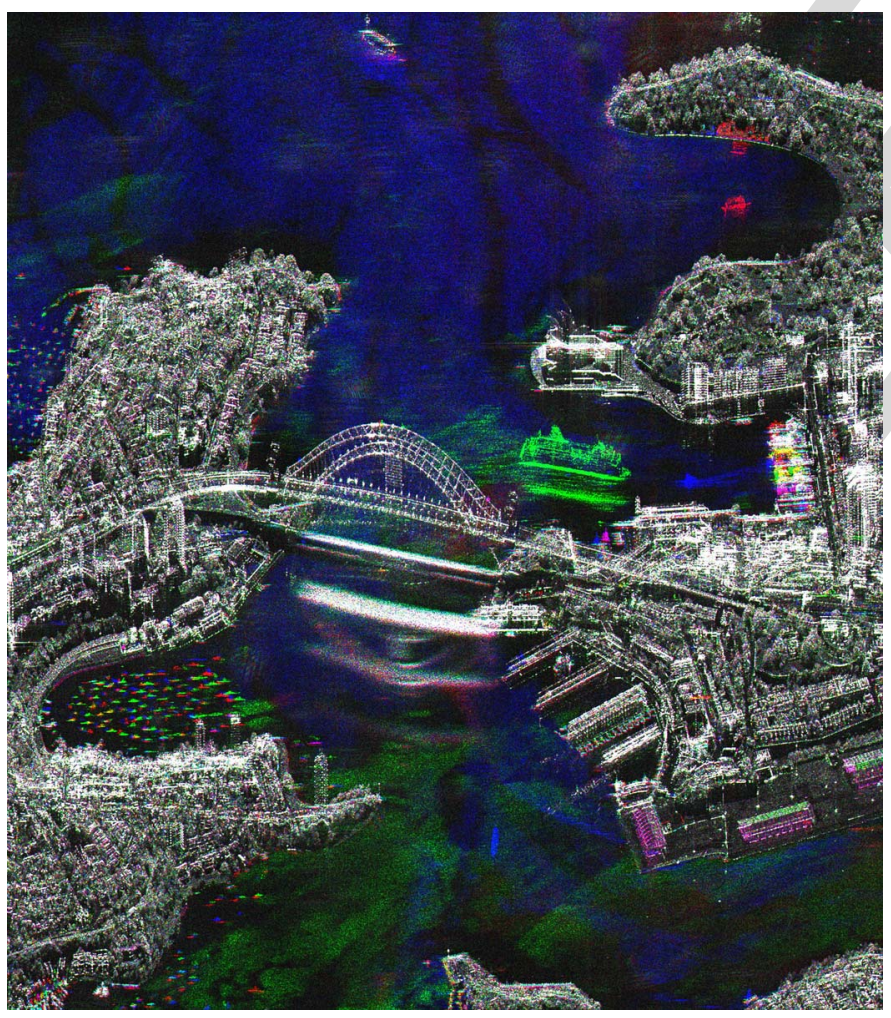

Fig. 9. Multitemporal high-resolution spotlight image of the Sydney harbor area. The three images were taken on (green) December 21, 2007, (blue) January 1, 2008, and (red) January 12, 2008. Objects, which have not changed in between the acquisitions, appear white.

radar image is due to the well-known foreshortening effect of side-looking imaging radars.

Fig. 9 also shows a high-resolution spotlight image but, this time, a multitemporal repeat-pass acquisition of the Sydney harbor area. Three color-coded images taken on December 21,

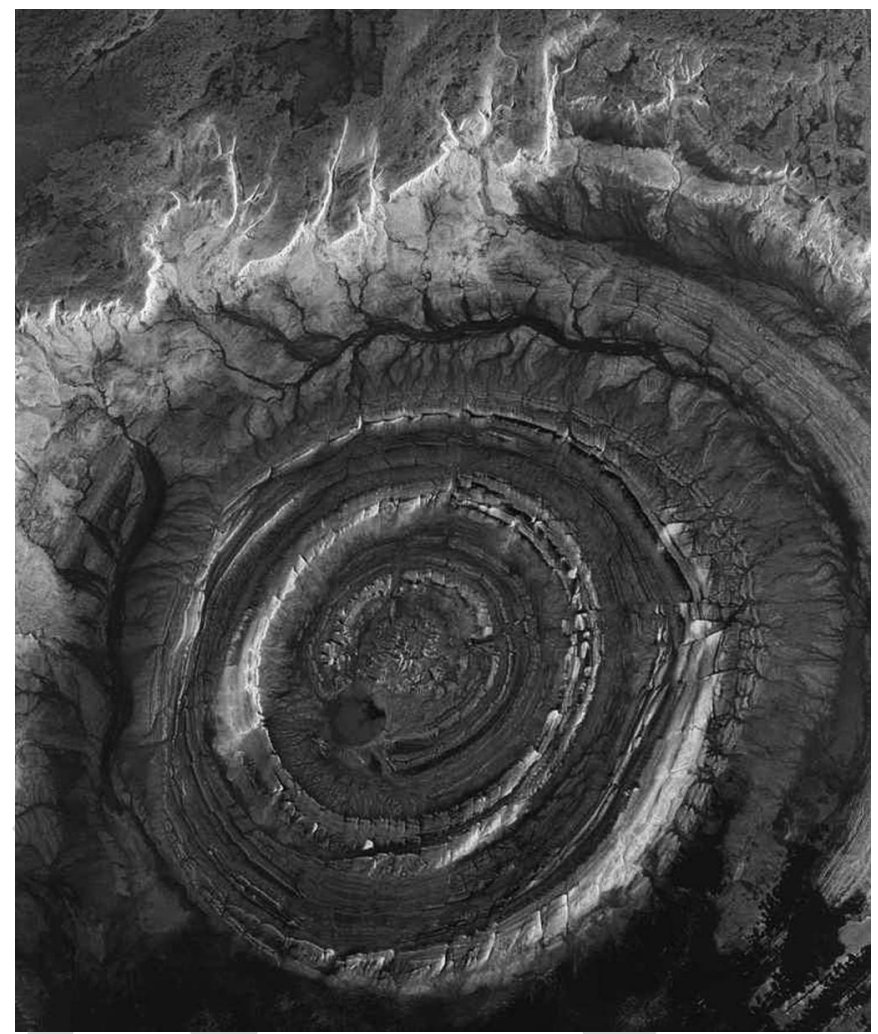

Fig. 10. TerraSAR-X image of the Guelb er Richat ring structure in Mauritania. The image was taken on July 8, 2007; original resolution: 16 m; mode: ScanSAR mode; polarization: VV.

2007 (green), January 1, 2008 (blue), and January 12, 2008 (red), have been overlayed. Objects, which have not changed in between the acquisitions, appear white. Objects, which have been present only at the time of one of the acquisitions-like the ship (green) close to the bridge-appear in the corresponding color. The radar reflection of the water surface is different in each of the images, giving the water body its special appearance. The center of the image is dominated by the impressive Sydney Harbour Bridge.

Aside from the stripmap and spotlight mode, ScanSAR is the third standard imaging mode of TerraSAR-X. It allows wide area coverage in up to $100-\mathrm{km}$-wide swathes with reduced resolution. Fig. 10 shows an image example of the Guelb er Richat in Mauritania. The ring structure shown in this image has a diameter of about $45 \mathrm{~km}$ and is located in Ouadane. The ring consists of limestones, dolomites, and breccias from the late Proterozoic to Ordovician eras (aged about 0.6 to 0.5 billion years) that were centrally uplifted and subsequently eroded. The question as to the structure's origin, which is widely thought to have been originally a meteorite crater, has not been finally answered. Although the exposed layers have formed a shallow ridge which, in many parts, is no more than a few meters high, the structure can excellently be identified and mapped in a radar image due to its surface properties.

In addition to the standard imaging modes, TerraSAR-X features the experimental DRA mode, which allows for along-track interferometry measurements (see also the related TGRS article [46] in this Special Issue), as well as fullpolarimetric data acquisitions. Fig. 11 shows an example of a 


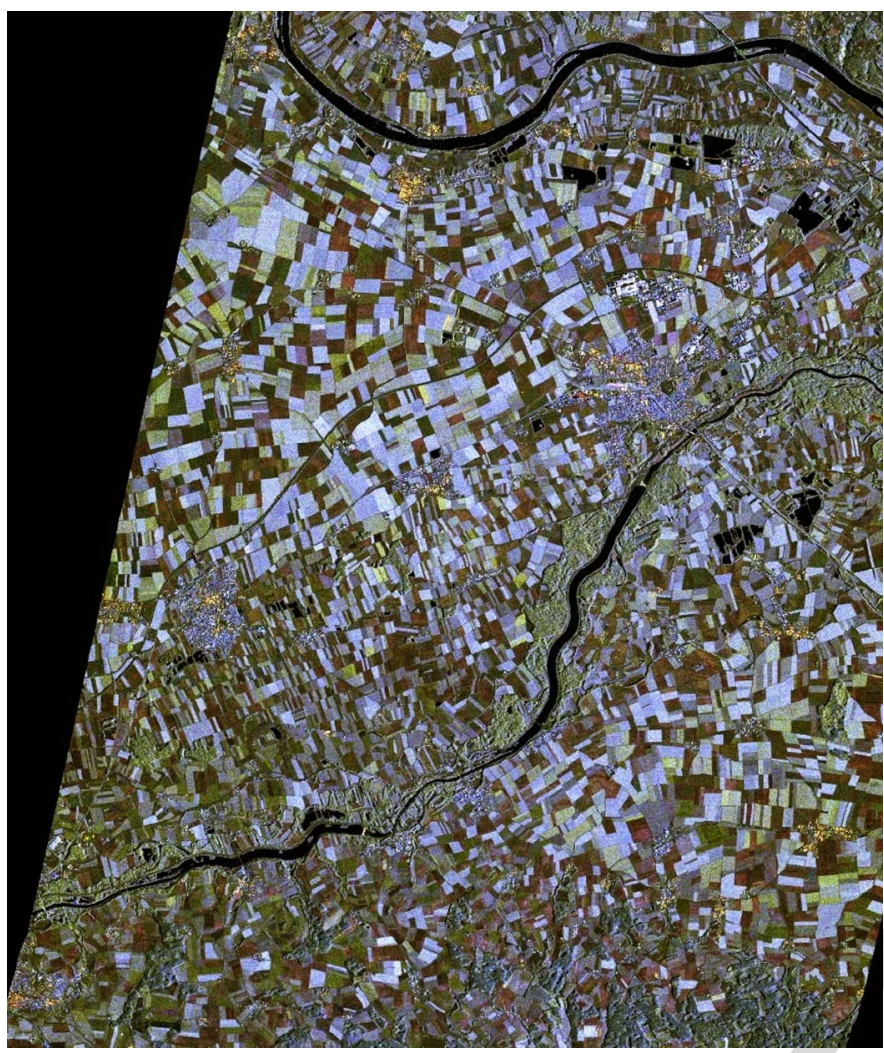

Fig. 11. One of the first images acquired in the fully polarimetric experimental mode of TerraSAR-X. The different information layers correspond to different colors. (Red) HH channel. (Green) VV channel. (Blue) (HV + VH)/2 channel.

full-polarimetric image taken in the DRA mode. The scene is located approximately $130 \mathrm{~km}$ north of Munich in the region of Deggendorf, Germany. It represents a typical agricultural cultivated area with some small forest parts and smaller urbanized areas. The use of SAR polarimetry enhances the information content because it allows separating different scattering mechanisms occurring within one resolution cell and is sensitive to the geometry and the material properties of the illuminated object. This can perfectly be illustrated by the colored image, where the different information layers correspond to different colors. The agricultural areas are represented by a variety of different colors representing the agricultural crop growth status: green fields representing nonvegetated fields, red one representing the sensitivity to the interaction between the surface and the plant stalks, and blue fields indicating dense vegetated areas. In the case that all scattering information occurs within one resolution cell, then the color combination is white.

Another outstanding feature of TerraSAR-X is its excellent interferometric performance. In combination with the high geometric resolution of the radar sensor, interesting new results can be obtained particularly in urban areas by generating high-resolution interferograms. Fig. 12 shows a zoom into a $300-\mathrm{MHz}$ high-resolution spotlight interferogram of Paris, France, at the location of the Eiffel Tower [47]. The orientation of the images generates a pseudoperspective view of the tower and larger buildings which are laid over other areas. The images were taken on January 16 and 27, 2008, with a 300-MHz range bandwidth at an incidence angle of $34.7^{\circ}$ and a baseline of $49 \mathrm{~m}$. One fringe corresponds to a 321-m height difference which is, by chance, exactly the height of the tower. The orig-

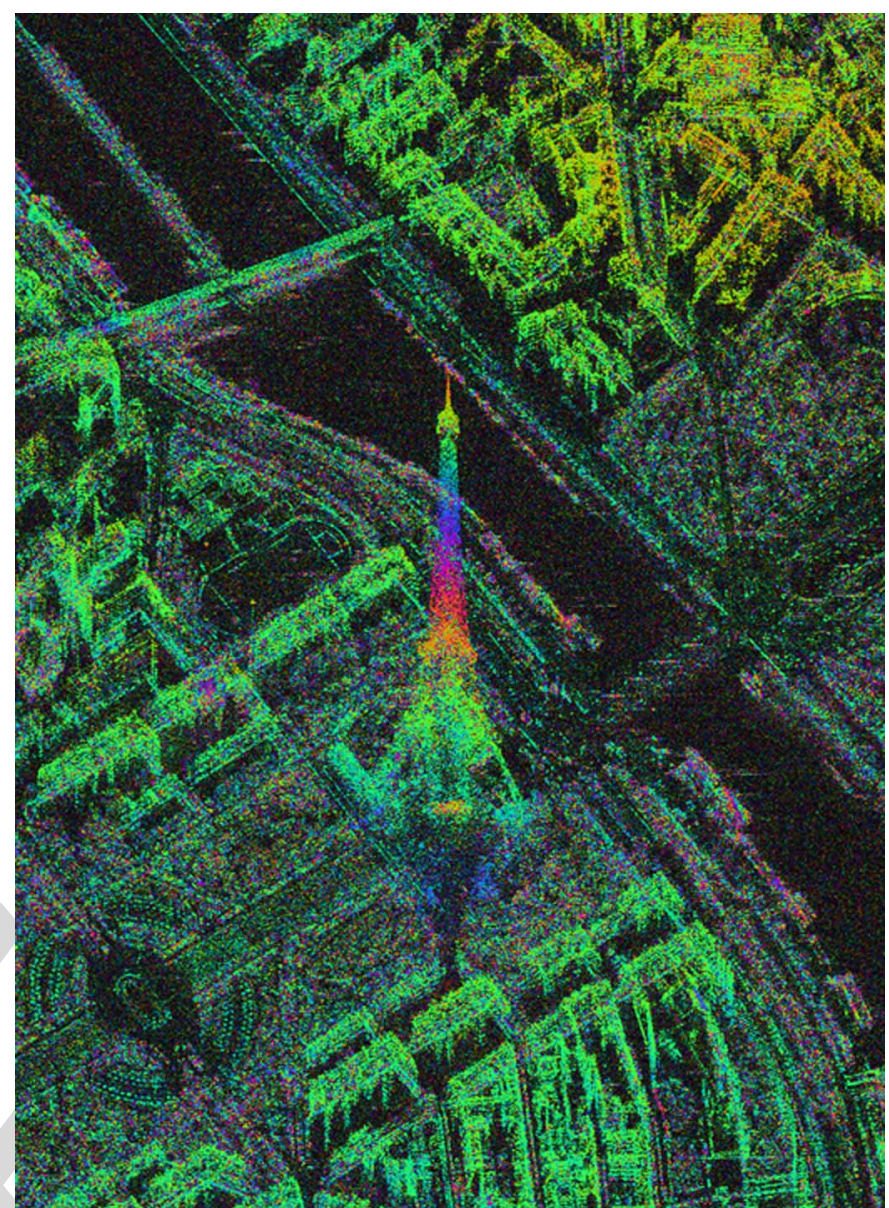

Fig. 12. Zoom into the Eiffel Tower of a high-resolution spotlight interferogram of Paris, France. The images were taken on January 16 and 27, 2008, with a $300-\mathrm{MHz}$ range bandwidth at an incidence angle of $34.7^{\circ}$ and a baseline of $49 \mathrm{~m}$.

inal interferogram features the phase stability over the whole scene without artifacts, the overall coherence in urban builtup areas, and the decorrelation in vegetated park areas after 11 days.

\section{CONCLUSION}

The launch of TerraSAR-X into orbit has been realized for the first time in Germany, an EO project by a PPP with considerable financial contribution by the industry. This enabled an innovative mission to be carried out which could not have been financed otherwise, a mission with a large potential for scientific use, as well as for the sustainable commercialization of EO data.

The mission provides a new class of high-quality X-band SAR products due to its high-resolution capability and the high flexibility of its antenna. In addition, it provides the capability of repeat-pass interferometry. The new DRA mode offers new applications like along-track interferometry and fullpolarimetric data acquisition.

As a next step in Germany's SAR roadmap, DLR and EADS Astrium are currently preparing the TanDEM-X mission [48], [49], scheduled to be launched by the end of 2009. The TanDEM-X mission will feature a second TerraSAR-X-type satellite that will fly in a close formation with TerraSAR-X 


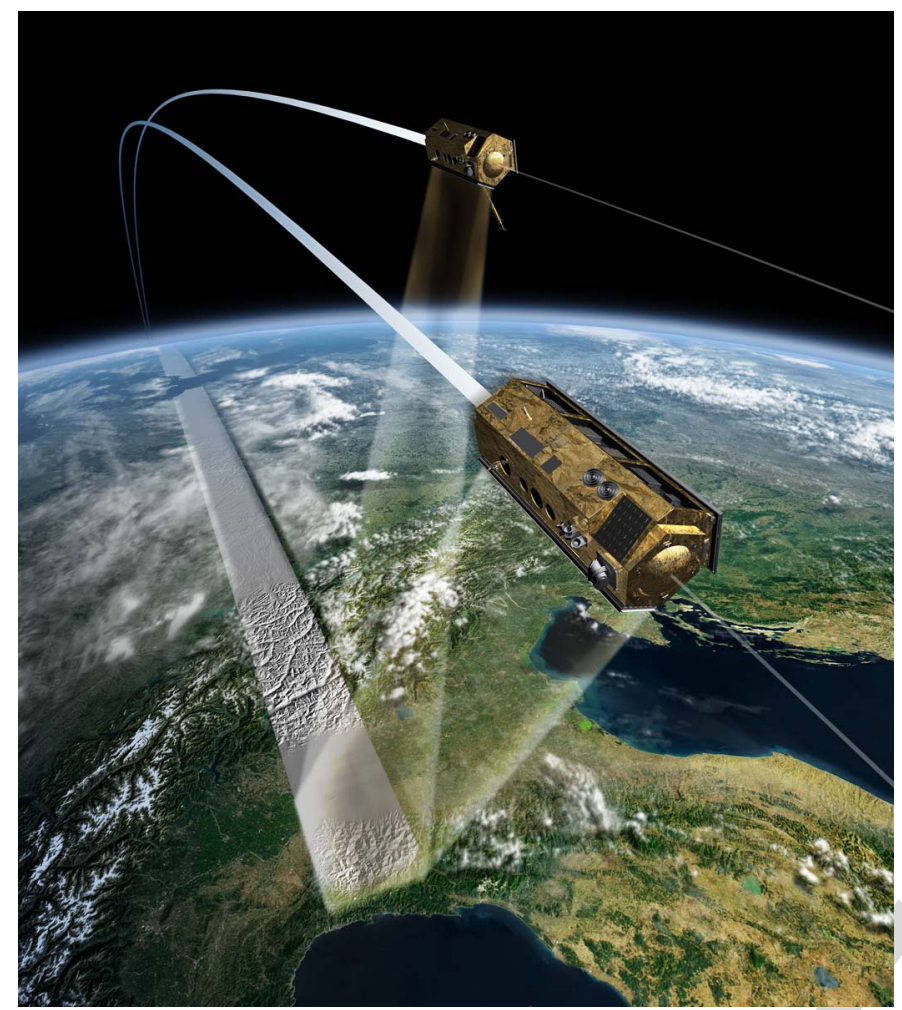

Fig. 13. Artist view of the TerraSAR-X and TanDEM-X satellites flying in close formation. The main goal of the TanDEM-X mission will be the acquisition of a global high-quality DEM with high resolution.

(Fig. 13). The main goal of the TanDEM-X mission will be the acquisition of a global high-quality DEM fulfilling the High-Resolution Terrain Information Level 3 specification. In addition, a new technology development is presently being conducted by DLR, investigating the high-resolution wide-swath concept for a future SAR mission after TanDEM-X, which allows overcoming the restrictions of conventional SAR systems with respect to simultaneously achieved high resolution and wide area coverage [50].

\section{REFERENCES}

[1] R. Werninghaus, S. Buckreuss, and W. Pitz, "TerraSAR-X mission status," in Proc. IEEE IGARSS, Barcelona, Spain, 2007, pp. 3927-3930.

[2] TX-PGS-PL-4001 TerraSAR-X Science Plan2004, Nov. 25.

[3] R. Werninghaus, "TerraSAR-X, a national German radar mission realised in public, private partnership," Q. Bull. Council Eur. Aerosp. Soc., May 10-23, 2008.

[4] S. Buckreuss, R. Werninghaus, and W. Pitz, "The German satellite mission TerraSAR-X," in Proc. IEEE RadarCon, Rome, Italy, 2008, pp. 1-5.

[5] D. Miller and W. Pitz, "The TerraSAR-X satellite," IEEE Trans. Geosci. Remote Sens., vol. 48, no. 2, Feb. 2010, to be published.

[6] B. D. Tapley, S. Bettadpur, M. Watkins, and C. Reigber, "The gravity recovery and climate experiment: Mission overview and early results," Geophys. Res. Lett., vol. 31, no. 9, p. L09 607, May 8, 2004, DOI: 10.1029/2004GL019920.

[7] M. Stangl, R. Werninghaus, and R. Zahn, "The TerraSAR-X active phased array antenna," in Proc. Phased Array, 2003, pp. 70-75.

[8] M. Stangl, R. Werninghaus, B. Schweizer, C. Fischer, M. Brandfass, J. Mittermayer, and H. Breit, "TerraSAR-X technologies and first results," Proc. Inst. Elect. Eng.-Radar, Sonar Navig., vol. 153, no. 2, pp. 86-95, Apr. 2006.

[9] M. Suess, S. Riegger, W. Pitz, and R. Werninghaus, "TerraSAR-XDesign and performance," in Proc. EUSAR, Köln, Germany, 2002.

[10] J. Mittermayer and H. Runge, "Conceptual studies for exploiting the TerraSAR-X dual receive antenna," in Proc. IEEE IGARSS, 2003, pp. 2140-2142.
[11] J. Mittermayer, V. Alberga, S. Buckreuss, and S. Riegger, "TerraSAR-X: Predicted performance," Proc. SPIE, vol. 4881, pp. 244-255, Sep. 22-27, 2002.

[12] R. Lange and B. Smutny, "BPSK laser communication terminals to be verified in space," in Proc. IEEE MILCOM, Oct. 31-Nov. 3, 2004, vol. 1, pp. 441-444.

[13] M. Rothacher, B. D. Tapley, C. Reigber, R. Koenig, C. Falck, L. Grunwaldt, W. Koehler, F.-H. Massmann, and G. Michalak, "The tracking, occultation and ranging (TOR) instrument onboard TerraSAR-X and on TanDEM-X," in Proc. IEEE IGARSS, Jul. 23-28, 2007, pp. 4983-4986.

[14] Y. T. Yoon, M. Eineder, N. Yague-Martinez, and O. Montenbruck, "TerraSAR-X precise trajectory estimation and quality assessment," IEEE Trans. Geosci. Remote Sens., vol. 47, no. 6, pp. 1859-1868, Jun. 2009.

[15] S. Buckreuss and B. Schättler, "The TerraSAR-X ground segment," IEEE Trans. Geosci. Remote Sens., vol. 48, no. 2, Feb. 2010, to be published.

[16] E. Maurer, F. Mrowka, A. Braun, C. Lenzen, Y. Wasser, M. P. Geyer, and M. Wickler, "TerraSAR-X mission planning system: Autonomous command generation for spacecraft operations," IEEE Trans. Geosci. Remote Sens., vol. 48, no. 2, Feb. 2010, to be published.

[17] S. Buckreuss, P. Mühlbauer, J. Mittermayer, W. Balzer, and R. Werninghaus, "The TerraSAR-X ground segment," in Proc. EUSAR, Dresden, Germany, 2006.

[18] U. Steinbrecher, D. Schulze, J. Böer, and J. Mittermayer, "TerraSAR-X instrument operations rooted in the system engineering and calibration project," IEEE Trans. Geosci. Remote Sens., vol. 48, no. 2, Feb. 2010, to be published

[19] B. Bräutigam, J. H. González, M. Schwerdt, and M. Bachmann, "TerraSAR-X instrument calibration results and extension for TanDEM-X," IEEE Trans. Geosci. Remote Sens., vol. 48, no. 2, Feb. 2010, to be published.

[20] J. Mittermayer, B. Schättler, and M. Younis, "TerraSAR-X commissioning phase execution summary," IEEE Trans. Geosci. Remote Sens., vol. 48, no. 2, Feb. 2010, to be published.

[21] J. Mittermayer, B. Schättler, and M. Younis, "TerraSAR-X commissioning phase execution and results," in Proc. IEEE IGARSS, Boston, MA, 2008, pp. II-197-II-200.

[22] J. Mittermayer, M. Younis, B. Bräutigam, T. Fritz, R. Kahle, and R. Metzig, "Verification of TerraSAR-X system," in Proc. IEEE IGARSS, Barcelona, Spain, 2007, pp. 4929-4932.

[23] R. Metzig, B. Bräutigam, D. Polimeni, J. Böer, M. Bachmann, and J. Mittermayer, "TerraSAR-X instrument characterization/verification," in Proc. 7th Eur. Conf. Synthetic Aperture Radar, Friedrichshafen, Germany, 2008.

[24] J. Mittermayer, U. Steinbrecher, A. Meta, N. Tous-Ramon, S. Wollstadt, M. Younis, J. Marquez, D. Schulze, and C. Ortega, "TerraSAR-X system performance and command generation," in Proc. 7th Eur. Conf. Synthetic Aperture Radar, Friedrichshafen, Germany, 2008.

[25] J. Marquez-Martinez, C. Gonzalez, M. Younis, S. Wollstadt, R. Metzig, U. Steinbrecher, N. Tous-Ramon, A. Meta, and J. Mittermayer, "In-orbit SAR performance of TerraSAR-X," in Proc. IEEE IGARSS, Barcelona, Spain, 2007, p. 3931.

[26] J. Mittermayer, M. Younis, R. Metzig, S. Wollstadt, J. Márquez, and A. Meta, "TerraSAR-X system performance characterization and verification," IEEE Trans. Geosci. Remote Sens., vol. 48, no. 2, Feb. 2010, to be published.

[27] M. Schwerdt, B. Bräutigam, M. Bachmann, and B. Döring, "TerraSAR-X calibration-First results," in Proc. IEEE IGARSS, Barcelona, Spain, 2007, pp. 3932-3935.

[28] M. Schwerdt, B. Bräutigam, B. Döring, D. Schrank, and J. H. Gonzalez, "Final results of the efficient TerraSAR-X calibration method," in Proc. Radarcon, Rome, Italy, 2008, pp. 1-6.

[29] M. Bachmann, M. Schwerdt, and B. Bräutigam, "TerraSAR-X antenna calibration and monitoring based on a precise antenna model," IEEE Trans. Geosci. Remote Sens., vol. 48, no. 2, Feb. 2010, to be published.

[30] T. Fritz, H. Breit, B. Schättler, U. Balss, M. Lachaise, and M. Eineder, "TerraSAR-X image products: Characterization and verification," in Proc. EUSAR Conf., Friedrichshafen, Germany, 2008.

[31] E. Mikusch, M. Wolfmüller, E. Diedrich, D. Dietrich, and M. Böttcher, "Management of 'future products' in the distributed payload ground segment for TerraSAR-X," in Proc. DASIA, 2003, p. 11.1.

[32] M. Wickler, A. Braun, and M. Geyer, "A strategic mission planning concept for TerraSAR-X," in Proc. 8th Int. Symp. Space Mission Oper. Ground Data Syst., Montreal, QC, Canada, 2004.

[33] H. Breit, T. Fritz, B. Schättler, E. Börner, M. Lachaise, A. Niedermeier, M. Eineder, and U. Balss, "TerraSAR-X payload data processing-First experiences," in Proc. IEEE IGARSS, Barcelona, Spain, 2007, p. 3936. 
[34] B. Schättler, T. Fritz, H. Breit, N. Adam, U. Balss, M. Lachaise, M. Eineder, and A. Niedermeier, "TerraSAR-X SAR data processing from commissioning and early orbit phase," in Proc. EARSeL Joint Workshop Remote Sens., New Challenges High Resolution, Bochum, Germany, 2008.

[35] M. Eineder, N. Adam, R. Bamler, N. Yague-Martinez, and H. Breit, "TerraSAR-X spotlight SAR interferometry," IEEE Trans. Geosci. Remote Sens., vol. 47, no. 5, pp. 1524-1535, May 2009.

[36] S. Suchandt, H. Runge, M. Eineder, H. Breit, A. Kotenkov, and U. Balss, "First results of ground moving target analysis in TerraSAR-X data," in Proc. IEEE IGARSS, Barcelona, Spain, 2007, p. 3943.

[37] F. D. Zan and A. M. Guarnieri, "TOPSAR: Terrain observation by progressive scan," IEEE Trans. Geosci. Remote Sens., vol. 44, no. 9, pp. 2352-2360, Sep. 2006.

[38] A. Meta, J. Mittermayer, U. Steinbrecher, and P. Prats, "Investigations on the TOPSAR acquisition mode with TerraSAR-X," in Proc. IEEE IGARSS, Barcelona, Spain, 2007, pp. 152-155.

[39] A. Meta, P. Prats, U. Steinbrecher, J. Mittermayer, and R. Scheiber, "TerraSAR-X TOPSAR and ScanSAR comparison," in Proc. EUSAR Conf. TerraSAR- $X$ Image Products, Charact. Verification, Friedrichshafen, Germany, 2008.

[40] P. Prats, R. Scheiber, J. Mittermayer, A. Meta, and A. Moreira, "Processing of sliding spotlight and TOPS SAR data using baseband azimuth scaling," IEEE Trans. Geosci. Remote Sens., vol. 48, no. 2, Feb. 2010, to be published.

[41] J. Mittermayer, P. Prats, R. Scheiber, and U. Steinbrecher, "TOPS imaging with TerraSAR-X: Mode design and performance analysis," IEEE Trans. Geosci. Remote Sens., vol. 48, no. 2, Feb. 2010, to be published.

[42] H. Fiedler, E. Boerner, J. Mittermayer, and G. Krieger, "Total zero Doppler steering-A new method for minimizing the Doppler centroid," IEEE Geosci. Remote Sens. Lett., vol. 2, no. 2, pp. 141-145, Apr. 2005

[43] S. Lehner, J. Schulz-Stellenfleth, and S. Brusch, "TerraSAR-X measurements of wind fields, ocean waves and currents," in Proc. SEASAR, Jan. 21-25, 2008. DVD: SP-565, ESA, Frascati, Italy.

[44] Center for Satellite Based Crisis Information. [Online]. Available: http://www.zki.caf.dlr.de/

[45] H. Breit, T. Fritz, U. Balss, A. Niedermeier, M. Lachaise, and M. Vonavka, "TerraSAR-X SAR processing and products," IEEE Trans. Geosci. Remote Sens., vol. 48, no. 2, Feb. 2010, to be published.

[46] S. Suchandt, H. Runge, H. Breit, U. Steinbrecher, A. Kotenkov, and U. Balss, "Automatic extraction of traffic flows using TerraSAR-X along-track interferometry," IEEE Trans. Geosci. Remote Sens., vol. 48, no. 2, Feb. 2010, to be published.

[47] M. Eineder, N. Adam, R. Bamler, N. Yague-Martinez, and H. Breit, "Spaceborne spotlight SAR interferometry with TerraSAR-X," IEEE Trans. Geosci. Remote Sens., vol. 47, no. 5, pp. 1524-1535, May 2009.
[48] M. Bartusch, H. Berg, and O. Siebertz, "The TanDEM-X mission," in Proc. EUSAR Conf., Friedrichshafen, Germany, 2008.

[49] G. Krieger, A. Moreira, H. Fiedler, I. Hajnsek, M. Werner, M. Younis, and M. Zink, "A satellite formation for high-resolution SAR interferometry," IEEE Trans. Geosci. Remote Sens., vol. 45, no. 11, pp. 3317-3341, Nov. 2007.

[50] C. Fischer, C. Heer, G. Krieger, and R. Werninghaus, "A high resolution wide swath SAR," in Proc. EUSAR, Dresden, Germany.

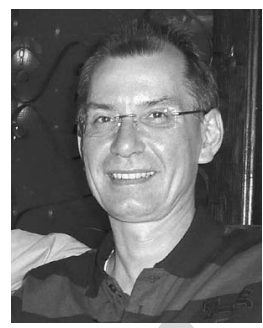

Rolf Werninghaus received the Dipl.Ing. degree in physics technology engineering from the Fachhochschule Hagen, Hagen, Germany, in 1980 and the M.Sc. in physics from the University of Dortmund, Dortmund, Germany, in 1988.

Since 1988, he has been with the German Aerospace Center (DLR), Bonn, Germany, where he started as a Project Engineer for the first SIR-C/ $\mathrm{X}-\mathrm{SAR}$ mission with the Project Management Department, Space Agency, and was the Project Manager for the second SIR-C/X-SAR mission on the NASA Space Shuttle from 1994 to 1996. Between 1996 and 2000, he was the Program Manager for the Shuttle Radar Topography Mission. In mid-2000, he was the TerraSAR-X Project Manager. Since 2007, he has been the Group Leader for the Earth Observation projects and missions with the German Space Agency.

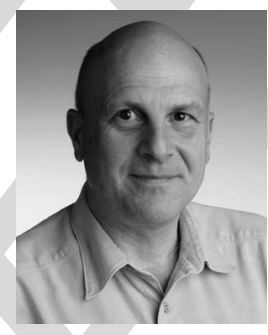

Stefan Buckreuss received the Dipl.Ing. degree in electronics from the Technical University of Munich, Munich, Germany, in 1988 and the Dr.Ing. degree from the University of Stuttgart, Stuttgart, Germany, in 1994.

Since 1988, he has been with the Microwaves and Radar Institute, German Aerospace Center (DLR), Wessling, Germany, where he gained broad experience in SAR signal processing and motion compensation, antijamming, and interferometry for DLR's airborne SAR system E-SAR. Within the scope of the international SRTM/X-SAR mission, he developed the online radar data analysis and quicklook processing tools for the X-SAR sensor. In 2002, he was engaged in the German TerraSAR-X mission, where he was responsible for the development of the instrument operations and calibration segment until he was assigned the role of Ground Segment Integration Manager. He is currently the TerraSAR-X Mission Manager and Designated Mission Manager for TanDEM-X. 